\title{
ON THE MOLLUSCAN FAUNA OF LAKSHADWEEP INCLUDED IN VARIOUS SCHEDULES OF WILDLIFE (PROTECTION) ACT OF INDIA
}

\section{A. Bijukumar ${ }^{1}$, R. Ravinesh ${ }^{2}$, A.R. Arathi ${ }^{3} \&$ K.K. Idreesbabu ${ }^{4}$}

ISSN 0974-7907 (Online) ISSN 0974-7893 (Print)

1,2,3 Department of Aquatic Biology and Fisheries, University of Kerala, Thiruvananthapuram, Kerala 695581, India

${ }^{4}$ Department of Science and Technology, Kavaratti, U.T. of Lakshadweep 682555, India

${ }^{1}$ bijupuzhayoram@gmail.com (corresponding author),, ${ }^{2}$ ravineshr08@gmail.com, ${ }^{3}$ arathichepla@gmail.com,

OPEN ACCESS

4 idreesbabu@gmail.com

Abstract: Out of the 24 species of marine molluscs included in Schedule I and IV of the Wildlife (Protection) Act (WPA) of India, 19 species were recorded from the coastal waters of Lakshadweep. A recent survey conducted by the authors recorded the presence of 14 scheduled molluscs in Lakshadweep. Scheduled species such as Placuna placenta (recorded from Kavaratti) and Tudicla spirillus (recorded from Kalpeni) are new records from Lakshadweep. The paper provides details for taxonomic identification of scheduled molluscs and discusses strategies for conservation of scheduled molluscs of Lakshadweep.

Keywords: Bivalvia, Cephalopoda, conservation, Gastropoda, Mollusca, Nautilus, Wildlife (Protection) Act.

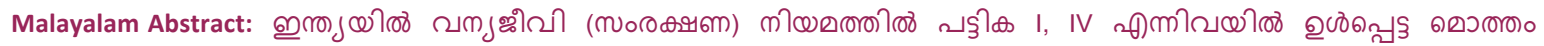

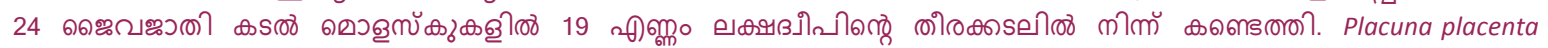

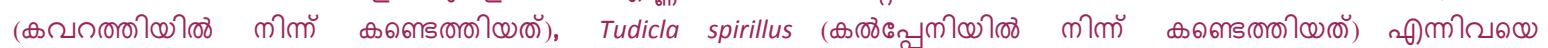

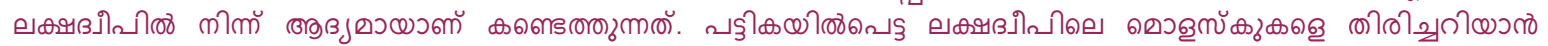

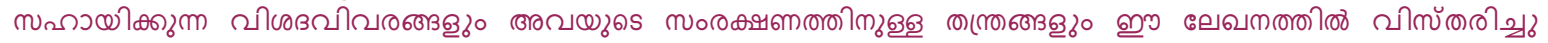

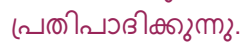
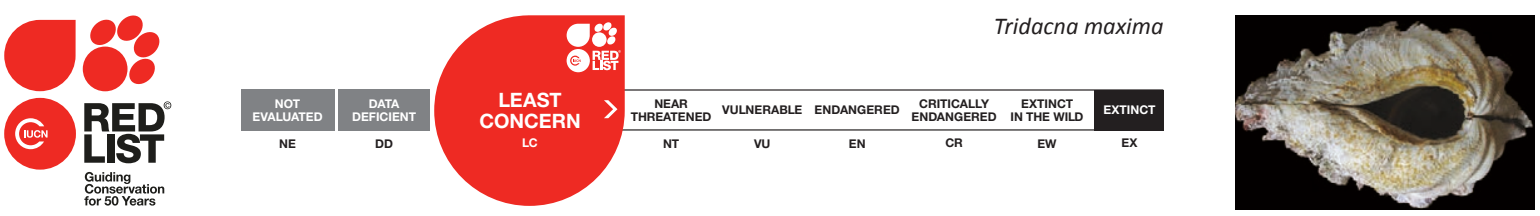

DOI: http://dx.doi.org/10.11609/JoTT.04140.7253-68 | ZooBank: urn:Isid:zoobank.org:pub:46141C50-3DFF-408E-A6B5-0963AF23AA7F

Editor: Anonymity requested.

Date of publication: 26 May 2015 (online \& print)

Manuscript details: Ms \# 04140 | Received 02 September 2014 | Final received 30 April 2015 | Finally accepted 02 May 2015

Citation: Bijukumar, A., R. Ravinesh, A.R. Arathi \& K.K. Idreesbabu (2015). On the molluscan fauna of Lakshadweep included in various schedules of Wildlife (Protection) Act of India. Journal of Threatened Taxa 7(6): 7253-7268; http://dx.doi.org/10.11609/JoTT.04140.7253-68

Copyright: (C) Bijukumar et al. 2015. Creative Commons Attribution 4.0 International License. JoTT allows unrestricted use of this article in any medium, reproduction and distribution by providing adequate credit to the authors and the source of publication.

Funding: Department of Biotechnology, Government of India (BT/PR13602/AAQ/03/508/2010).

Competing interests: The authors declare no competing interests.

For Author Details and Author Contribution see end of this article.

Acknowledgements: The authors thank the Department of Biotechnology, Government of India for the financial support of the project (BT/PR13602/ AAQ/03/508/2010). The authors also thank the Department of Science and Technology (Permission F No. 42/4/2011-S\&T dated 28.1.2014; F No. 42/4/2011S\&T (Vol.1)/210 dated 09.03.2015) and the Department of Environment and Forests, Union Territory of Lakshadweep (Permission F. No. 16/8/2008-E\&F dated 7.5.2012 and 23.3.2013; F.No. 19/5/2012- E\&F dated 19.3.2015) for the official permission to study marine molluscs of the islands. Arathi thanks the taxonomy fellowship offered by the Kerala State Council for Science, Technology and Environment for the PhD programme. Identification of Tridacna spp. was confirmed by Dr. Jan Johan ter Poorten, Zoological Museum, Amsterdam. Good quality photographs of Lambis indomaris were given by Mr. Ulrich Wieneke, Murnau, Germany. Thanks are due to $\mathrm{M} / \mathrm{s}$ Sandy Beach (Kavaratti) for their help in field work.
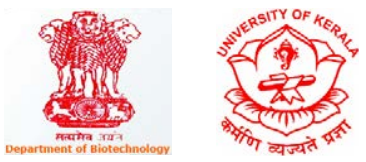


\section{INTRODUCTION}

Considered as biological hotspots and the legacy of a distinctive evolutionary history, island biodiversity is unique owing to taxonomic distinctness, endemism and specific habitat requirements (da Fonseca et al. 2006). Conversely, the risk of extinction of species is much more pronounced in islands as the populations are rather restricted, small and specific to certain habitats. Anthropogenic interventions have catastrophic effects on island biodiversity and therefore demand urgent attention of conservationists and policy makers. The Secretariat of the Convention on Biological Diversity (CBD) considered the theme of the International Day for Biological Diversity (IDB) on 22 May 2014 as "Island Biodiversity". In the case of Lakshadweep, the entire economy of the islands and the great cultural ethos of the islanders remain closely interlinked with the rich biodiversity. The threats to biodiversity are primarily due to unsustainable developmental activities, increase in human population, overexploitation and climate change (KSCSTE 2013).

Mollusca comprise highly diverse phylum of invertebrates, with accepted described living species of molluscs varying from 50,000 to a maximum of $1,20,000$ species, and form the largest marine phylum, comprising about $23 \%$ of all the named marine organisms (Chapman 2009). They form an economically valuable taxon and are well represented in exports of marine products and in domestic trade in the form of various products such as crafts, curios and pearls. In tropical seas they occupy every trophic level, ranging from primary producers to top level carnivores (Mohamed 2012). The diversity of marine molluscs in India is estimated as 3,370 species by Venkataraman \& Wafar (2005) and as 2,300 by Tripathy \& Mukhopadhyay (2015). The island ecosystems in India are highly biodiverse with regard to molluscan fauna. While the diversity of molluscan fauna of the Andaman and Nicobar Islands includes 1,282 species (Ramakrishna \& Dey 2010), in Lakshadweep there are about 424 species (Rao \& Rao 1991). A recent database prepared by KSCSTE (2013) shows that the molluscan diversity in Lakshadweep includes 469 species. Surveys on molluscan fauna of Lakshadweep by various authors in the last few decades are an indication of not having fully explored the molluscan diversity of the island and therefore the number of molluscan species is probably underestimated (Namboodiri \& Sivadas 1979; Appukuttan et al. 1989; Apte 1998, 2009, 2012a,b, 2014; Ramakrishna \& Dey 2010; Rao 2003; Apte \& Sutirtha 2010; Apte et al. 2010, 2012, 2014; Prabhakaran et al.
2012; Susan et al. 2012; Venkataraman et al. 2012; Aditi \& Apte 2013; Ravinesh et al. 2013; Vishal \& Apte 2013; Apte \& Vishal 2014).

Considering the increasing threats to marine biodiversity, the Government of India has included many marine species under the four schedules of Wildlife (Protection) Act (WPA), 1972 (http://envfor.nic. in/division/wildlife). Under Indian WPA the species to be protected are listed under Schedules I to VI. While Schedule I and II (Part II) species are covered by the most stringent regulations in the Act to get the highest level of legal protection, species in Schedules II (Part I), III and IV are given progressively narrow levels of protection; Schedule V represents species labelled 'vermin' which are not afforded protection of any kind and Schedule VI includes six plants (Prashanth \& Veenakumari 1996; Kunte 2008). A total of 24 species of marine molluscs of India have been included under Schedule I and IV of WPA (Ramakrishna \& Dey 2003). This paper documents 19 species of marine molluscs recorded from Lakshadweep, represented under various schedules of WPA, compiled from various databases/publications and also based on the primary data collected.

\section{MATERIALS AND METHODS}

India's smallest Union Territory Lakshadweep is an archipelago consisting of 36 islands with an area of $32 \mathrm{~km}^{2}$. It is a uni-district Union Territory and it comprises 12 atolls, three reefs, five submerged banks and 10 inhabited islands, which include Kavaratti, Agatti, Amini, Androth, Kiltan, Kalpeni, Kadamat, Chetlat, Bitra and Minicoy (Fig. 1). It is located between $8-12^{\circ} \mathrm{N}$ and $71-74{ }^{\circ} \mathrm{E}, 220-440 \mathrm{~km}$ away from the coastal city of Kochi in Kerala. The islands are ring-shaped atolls lying along a north-south axis (except Androth) with a lagoon to the west and open sea to the east. Lakshadweep is the only coral atoll of the country. With a vast lagoon of $4,200 \mathrm{~km}^{2}$, it has territorial waters of $20,000 \mathrm{~km}^{2}$, an Exclusive Economic Zone (EEZ) of $4,00,000 \mathrm{~km}^{2}$ and a coast line of about $132 \mathrm{~km}$. Lakshadweep, Maldives and Chagos are three island groups in the Indian Ocean that together form a vast submarine mountain range, the Chagos-Laccadive Plateau. This volcanic range lies just east of the Mid-Indian Ridge and west of the Mid-Indian Basin, and the chain of islands comprises the most extensive coral reef and atoll community in the Indian Ocean as well as the largest atoll system in the World (Olson \& Dinerstein 1998).

As part of the present study, surveys were carried out 

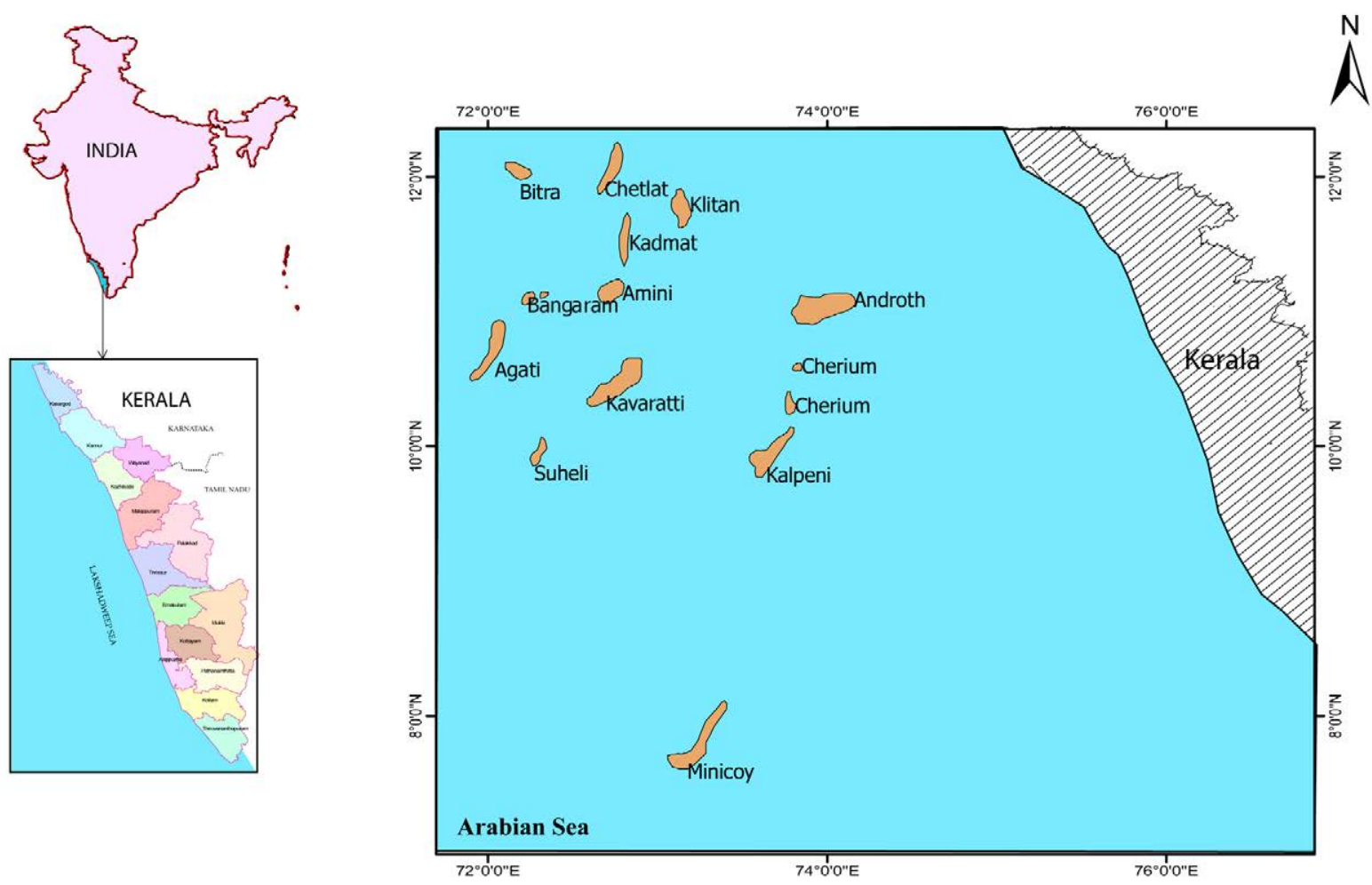

Figure 1. Lakshadweep islands

Dorsal

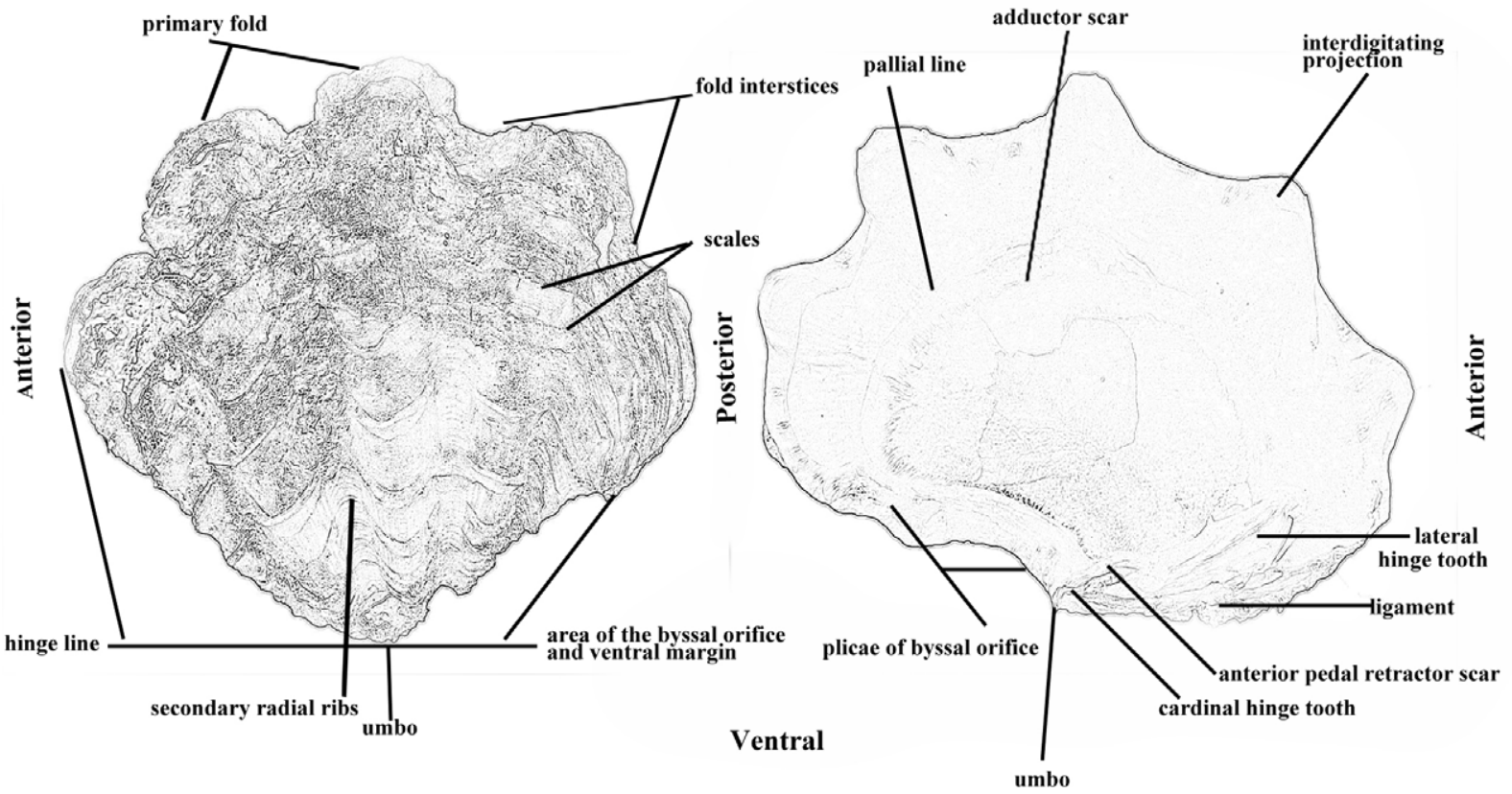

Figure 2. Generalised diagram of a bivalve mollusc

in Agatti, Androth, Bangaram (uninhabited island), Bitra, Kadamat, Kalpeni, Kavaratti and Minicoy islands for the documentation of molluscs at multiple intervals from January 2012 to September 2014. The organisms were photo documented using methods such as SCUBA diving, snorkelling and intertidal handpicking. The photographs of scheduled molluscs and their life history stages were prepared based on specimens photographed in the 


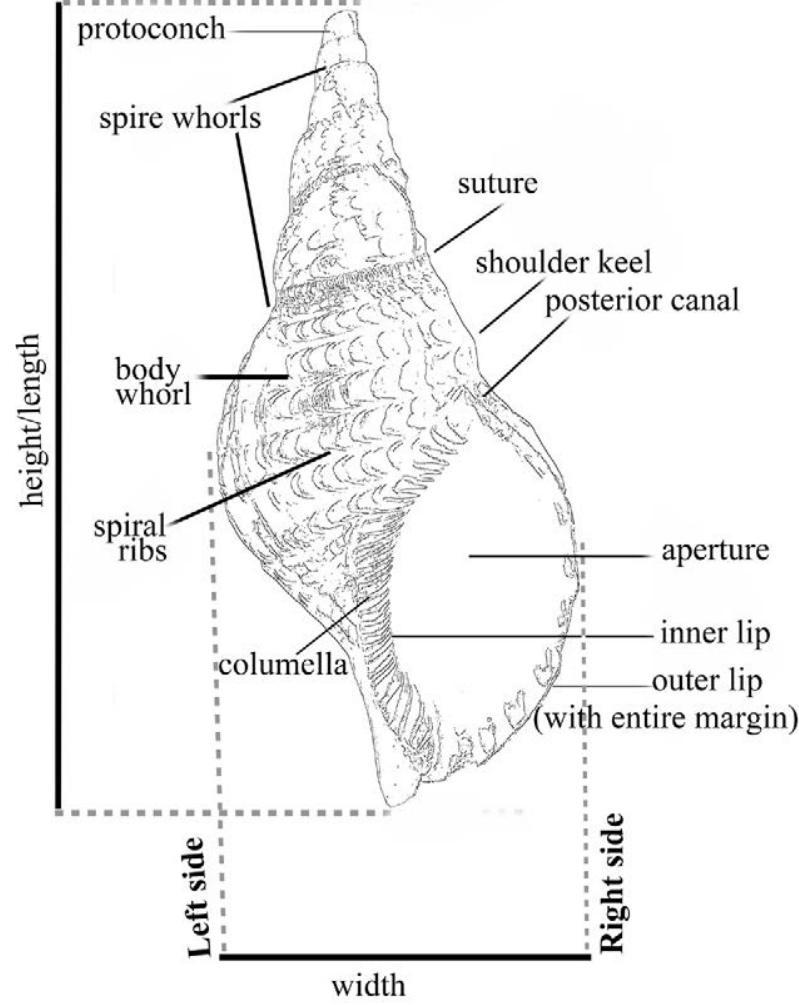

Figure 3. Generalised diagram of a gastropod mollusc

field or otherwise mentioned. Generalised diagrams of gastropod and bivalve molluscs are provided in Figs 2 and 3.

Secondary data collection was made from all the published records on molluscan fauna of the islands and available checklists (Appukuttan et al. 1989; Rao \& Rao 1991; Apte 1998; Rao 2003; Ramakrishna \& Dey 2010; Venkataraman et al. 2012; KSCSTE 2013; Apte 2014). A checklist of molluscs in various schedules of WPA of India was prepared with updated names and classification.

\section{RESULTS AND DISCUSSION}

The present survey recorded the presence of 14 species of molluscs representing the various schedules of WPA of India. Of these, Placuna placenta (Linnaeus, 1758) (recorded from Kavaratti) and Tudicla spirillus (Linnaeus, 1767) (recorded from Kalpeni) are new records from Lakshadweep. A checklist of marine molluscs in the various schedules of WPA and species recorded from Lakshadweep (Table 1) shows that 19 species of scheduled molluscs were recorded from the island ecosystem.
1. Harpago chiragra (Linnaeus, 1758) (Images 1a-k)

Appukuttan et al. 1989, p.79; Rao \& Rao 1991, p. 277; Ramakrishna \& Dey 2003, p 28; KSCSTE 2013, p. 146; Apte 1998, p.31; Apte 2014, p. 59.

Description: Very thick, robust, ovate and heavy shell, with a distinct anterior notch. Spire very obtuse and knotty. Six long and curved marginal digitations, expanded from the flaring, thick outer lip and canals (Image $1 \mathrm{i}, \mathrm{j}$ ). Anterior canal and posterior most digitation of outer lip with their bases recurved at right angle to the left side. Deep stromboid notch between $4^{\text {th }}$ and $5^{\text {th }}$ labial digitations. Whorls 9-11; the four uppermost whorls are depressed, so as to give the spire a truncated appearance and each of the other whorls have a row of strong rounded knobs. Inner lip serrated. White exterior with brown patches and flecks; aperture rose pink or orange interior. Columellar callus brown in specimens from Lakshadweep and Sri Lanka chocolate brown, and are distinct from Pacific specimens (unpublished data). Columella and aperture lirate (sculptured with fine lines or grooves). Operculum chitinous, dark brown, fusiform, with fine striations on one side.

In the initial developmental phases, $H$. chiragra shells have thin outer lips, without any fingers (Images 1a-d). As they grow, the outer lips become thick, expand and develop digits (Images $1 \mathrm{e}-\mathrm{h}$ ).

Shell length 280-320 mm; Maximum length 320mm.

Remarks: In Lakshadweep it is found around all inhabited islands (Appukuttan et al. 1989; Rao \& Rao 1991; Apte 1998, 2014; Rao 2003; KSCSTE 2013), often associated with a sandy bottom and algae-covered reefs. Found in littoral and sublittoral zones, in tidal pools and low tide levels to a depth of around $20 \mathrm{~m}$. This is a common strombid in Lakshadweep. The flesh of this species was earlier collected by the local people for the preparation of pickles. Included in Schedule IV of WPA of India. Not listed in CITES and not evaluated in IUCN Red List of Threatened Species. Currently the developmental stages are collected by the shell collectors without knowing its identity. Further, the juvenile stages of this species are almost impossible to distinguish from the juveniles of Harpago arthriticus.

\section{Harpago arthriticus (Röding, 1798) (Images 2 a-c)}

Apte 1998, p.32; Apte 2014, p. 59.

Description: Shell thick, robust, ovate and heavy with five labial digitations. Siphonal canal turned to the left. It looks similar to $H$. chiragra, but differs from the same with slightly depressed, broad rounded arching on the end of aperture. This smaller species is with heavy whitish creamy plications in the aperture between which 


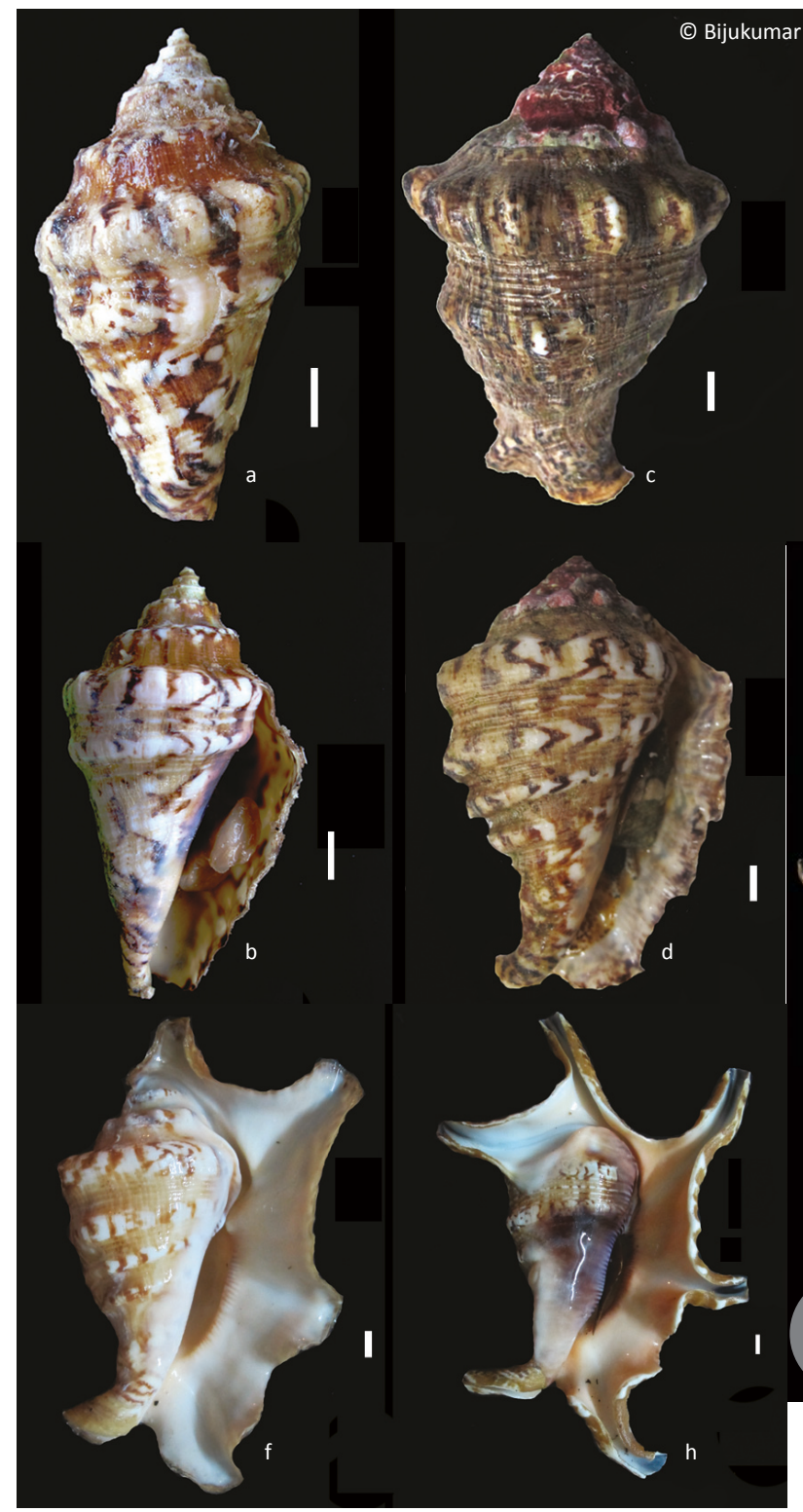

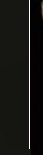
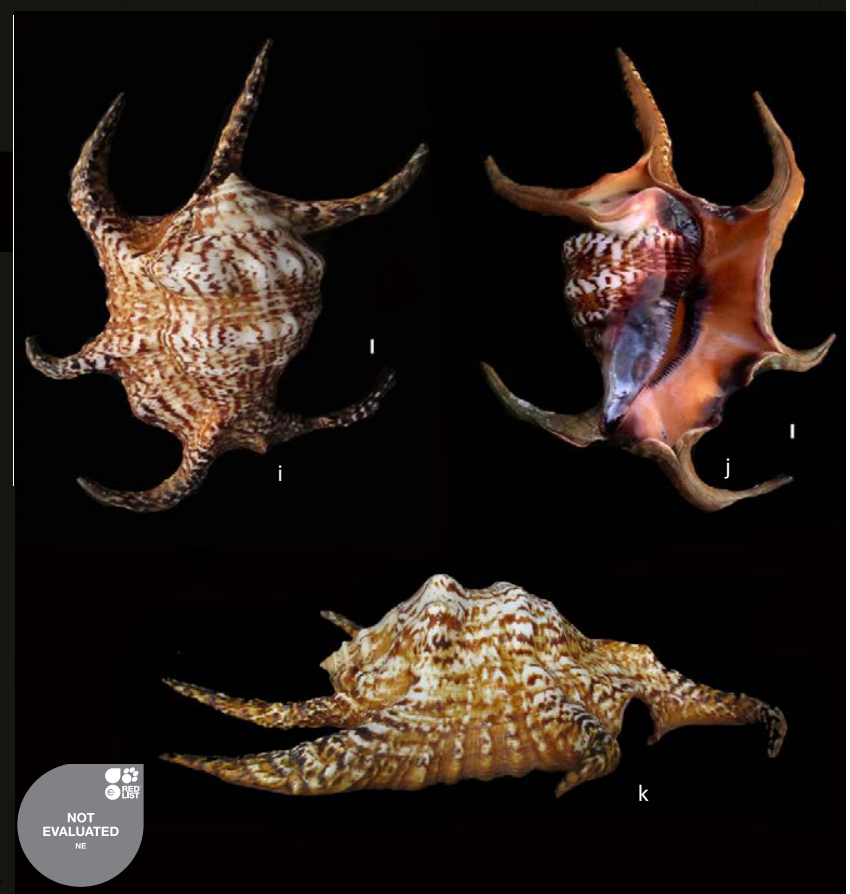

Image 1. Harpago chiragra Linnaeus.

$\mathrm{a}-\mathrm{h}$ - various life stages; $\mathrm{i}$ - dorsal view of adult shell; $\mathrm{j}$ - ventral view of adult shell; $\mathrm{k}$ - lateral view of adult shell $(\mathrm{scale}=1 \mathrm{~cm})$ are dark purplish, streaks, which help distinguishing the species. Large "stromboid notch" located between the $4^{\text {th }}$ and $5^{\text {th }}$ labial digitations. The outer lip is yellowish or pinkish yellow with splotches of purplish underlying the white spiral lirae. Columella brownish-purple; four spinal cords on the parietal wall. Peiostracum thin, varnish like. Operculum chitinous, auburn brown colour, fusiform, with fine striations on one side.

Remarks: In Lakshadweep it was recorded from Kalpeni (Apte 1998, 2014) and is rare in occurrence. Included in Schedule IV of WPA. Not listed in CITES. Not evaluated by IUCN Red List of Threatened Species. The juvenile stages of this species are difficult to distinguish from the juveniles of $H$. chiragra.

\section{Lambis crocata (Link, 1807) (Images 3 a-c)}

Apte 2014, p. 60.

Description: Shape irregular with long, slender, curved siphonal digitations. The whorls are encircled by three rows of small knobs and many spiral threads. The spines on the outer lip, including the one enveloping the posterior canal, are tubular in structure, but are usually filled up when the shell has fully grown, whereas only the most anterior spine remains tubular as the anterior canal. Anterior canal expanded in a very long and slender digitation. The outer surface is white in colour 
Table 1. List of marine molluscs in various Schedules of Wildlife (Protection) Act of India

\begin{tabular}{|c|c|c|c|c|c|}
\hline & Classification & Common Name & $\begin{array}{l}\text { Category in } \\
\text { WPA }\end{array}$ & $\begin{array}{l}\text { Records from } \\
\text { Lakshadweep }\end{array}$ & References \\
\hline 1. & $\begin{array}{l}\text { Phylum: Mollusca } \\
\text { Class: Gastropoda } \\
\text { Subclass: Vetigastropoda } \\
\text { Superfamily: Trochoidae } \\
\text { Family: Tegulidae } \\
\text { Tectus niloticus (Linnaeus, 1767) }\end{array}$ & Top Shell & Schedule IV & Not recorded & \\
\hline 2. & $\begin{array}{l}\text { Family: Turbinidae } \\
\text { Turbo marmoratus Linnaeus, } 1758\end{array}$ & $\begin{array}{l}\text { Great Green } \\
\text { Turbon }\end{array}$ & Schedule IV & Not recorded & \\
\hline 3. & $\begin{array}{l}\text { Subclass : Caenogastropoda } \\
\text { Order: Littorinimorpha } \\
\text { Family: Strombidae } \\
\text { Dolomena plicata sibbaldi (G.B. } \\
\text { Sowerby II, 1842) }\end{array}$ & Sibbald's Conch & Schedule IV & $\begin{array}{l}\text { Recorded from } \\
\text { Lakshadweep; specific } \\
\text { locality not mentioned. }\end{array}$ & Apte 2014 \\
\hline 4. & Harpago chiragra (Linnaeus, 1758) & $\begin{array}{l}\text { Chiragra Spider } \\
\text { Conch }\end{array}$ & Schedule IV & $\begin{array}{l}\text { Found around all } \\
\text { inhabited islands of } \\
\text { Lakshadweep }\end{array}$ & $\begin{array}{l}\text { Appukuttan et al. (1989), Rao \& Rao (1991), } \\
\text { Apte (1998), Rao (2003), KSCSTE (2013), Apte } \\
\text { (2014), Present study }\end{array}$ \\
\hline 5. & Harpago arthriticus (Röding, 1798) & $\begin{array}{l}\text { Arthritic Spider } \\
\text { Conch }\end{array}$ & Schedule IV & Kalpeni & $\begin{array}{l}\text { Rao \& Rao (1991), Apte (1998), Rao (2003), } \\
\text { KSCSTE (2013), Apte (2014), Present study }\end{array}$ \\
\hline 6. & Lambis crocata (Link, 1807) & $\begin{array}{l}\text { Orange Spider } \\
\text { Conch }\end{array}$ & Schedule IV & $\begin{array}{l}\text { Minicoy, Kalpeni, } \\
\text { Kavaratti }\end{array}$ & Apte 2014, Present study \\
\hline 7. & Lambis truncata ([Lightfoot], 1786) & $\begin{array}{l}\text { Truncate spider } \\
\text { Conch }\end{array}$ & Schedule IV & $\begin{array}{l}\text { Found around all } \\
\text { inhabited islands of } \\
\text { Lakshadweep }\end{array}$ & $\begin{array}{l}\text { Appukuttan et al. (1989), Rao \& Rao (1991), } \\
\text { Apte (1998), Rao (2003), KSCSTE (2013), Apte } \\
\text { 2014, Present study }\end{array}$ \\
\hline 8. & Lambis millepeda (Linnaeus, 1758) & $\begin{array}{l}\text { Milleped Spider } \\
\text { Conch }\end{array}$ & Schedule IV & Not recorded & \\
\hline 9. & $\begin{array}{l}\text { Lambis indomaris Abbott, 1961[Listed } \\
\text { as Lambis scorpius (Linnaeus, 1758)] }\end{array}$ & Scorpio Conch & Schedule IV & $\begin{array}{l}\text { Recorded from } \\
\text { Lakshadweep; specific } \\
\text { locality not mentioned. }\end{array}$ & Apte (1998), Apte (2014), Present study \\
\hline 10. & $\begin{array}{l}\text { Family: Cassidae } \\
\text { Cassis cornuta (Linnaeus, 1758) }\end{array}$ & Horned Helmet & Schedule I & $\begin{array}{l}\text { Minicoy, Kalpeni, } \\
\text { Androth, Bangaram }\end{array}$ & $\begin{array}{l}\text { Rao \& Rao (1991), Apte (1998), Rao (2003), } \\
\text { KSCSTE (2013), Apte (2014), Present study }\end{array}$ \\
\hline 11. & Cypraecassis rufa (Linnaeus, 1758) & $\begin{array}{l}\text { Bull Mouth } \\
\text { Helmet }\end{array}$ & Schedule I & $\begin{array}{l}\text { Minicoy, Kalpeni, } \\
\text { Androth, Bangaram, } \\
\text { Chetlet }\end{array}$ & $\begin{array}{l}\text { Appukuttan et al. (1989), Rao \& Rao (1991), } \\
\text { Apte (1998), Rao (2003), KSCSTE (2013), Apte } \\
\text { (2014), Present study }\end{array}$ \\
\hline 12. & $\begin{array}{l}\text { Family: Ranellidae } \\
\text { Charonia tritonis (Linnaeus, 1758) }\end{array}$ & Trumpet Triton & Schedule I & $\begin{array}{l}\text { Agatti, Amini, Chetlet, } \\
\text { Kalpeni }\end{array}$ & $\begin{array}{l}\text { Appukuttan et al. (1989), Rao \& Rao (1991), } \\
\text { Apte (1998), Rao (2003), KSCSTE (2013), Apte } \\
\text { 2014, Present study }\end{array}$ \\
\hline 13 & $\begin{array}{l}\text { Family: Cypraeidae } \\
\text { Staphylaea limacina (Lamarck, 1810) }\end{array}$ & $\begin{array}{l}\text { Limacina } \\
\text { Cowrie }\end{array}$ & Schedule IV & $\begin{array}{l}\text { Recorded from } \\
\text { Lakshadweep; specific } \\
\text { locality not mentioned. }\end{array}$ & Apte (2014) \\
\hline 14 & $\begin{array}{l}\text { Leporicypraea mappa (Linnaeus, } \\
\text { 1758) }\end{array}$ & Map cowrie & Schedule IV & $\begin{array}{l}\text { Recorded from } \\
\text { Lakshadweep; specific } \\
\text { locality not mentioned. }\end{array}$ & Apte (2014) \\
\hline 15 & Talparia talpa (Linnaeus, 1758) & Mole Cowrie & Schedule IV & Kavaratti, Kalpeni & $\begin{array}{l}\text { Appukuttan et al. (1989), Rao \& Rao (1991), } \\
\text { Apte (1998), Rao (2003), KSCSTE (2013), Apte } \\
\text { (2014), Present study }\end{array}$ \\
\hline 16. & $\begin{array}{l}\text { Order: Neogastropoda } \\
\text { Family: Turbinellidae } \\
\text { Tudicla spirillus (Linnaeus, 1767) }\end{array}$ & Dog Chunk & Schedule I & Kalpeni, Bitra & Present study \\
\hline 17. & $\begin{array}{l}\text { Family: Conidae } \\
\text { Conus milneedwardsi } \\
\text { Jousseaume, } 1894\end{array}$ & Glory of India & Schedule I & Not recorded & \\
\hline 18. & $\begin{array}{l}\text { Family: Fasciolariidae } \\
\text { Pleuroploca trapezium (Linnaeus, } \\
\text { 1758) }\end{array}$ & $\begin{array}{l}\text { Trapezium } \\
\text { Horse Conch }\end{array}$ & Schedule IV & $\begin{array}{l}\text { Recorded from } \\
\text { Lakshadweep; specific } \\
\text { locality not mentioned. }\end{array}$ & Apte (2014) \\
\hline 19. & $\begin{array}{l}\text { Family: Volutidae } \\
\text { Harpulina arausiaca (Ligthfoot, 1786) }\end{array}$ & Vaxillate Volute & Schedule IV & $\begin{array}{l}\text { Recorded from } \\
\text { Lakshadweep; specific } \\
\text { locality not mentioned. }\end{array}$ & Apte (2014) \\
\hline 20. & $\begin{array}{l}\text { Class: Bivalvia } \\
\text { Subclass: Pteriomorphia } \\
\text { Order: Pectinoida } \\
\text { Family: Placunidae } \\
\text { Placuna placenta } \\
\text { (Linnaeus, 1758) }\end{array}$ & $\begin{array}{l}\text { Window Pane } \\
\text { Oyster }\end{array}$ & Schedule IV & Kavaratti & Present study \\
\hline 21. & $\begin{array}{l}\text { Subclass: Heterodonta } \\
\text { Order: Veneroida } \\
\text { Superfamily: Cardioidea } \\
\text { Family: Cardiidae } \\
\text { Tridacna maxima (Röding, 1798) }\end{array}$ & $\begin{array}{l}\text { Elongate Giant } \\
\text { Clam }\end{array}$ & Schedule I & $\begin{array}{l}\text { Found around all } \\
\text { inhabited islands of } \\
\text { Lakshadweep }\end{array}$ & $\begin{array}{l}\text { Appukuttan et al. (1989), Rao \& Rao (1991), } \\
\text { Apte (1998), Rao (2003), KSCSTE (2013), } \\
\text { Present study }\end{array}$ \\
\hline
\end{tabular}




\begin{tabular}{|c|c|c|c|c|c|}
\hline & Classification & Common Name & $\begin{array}{l}\text { Category in } \\
\text { WPA }\end{array}$ & $\begin{array}{l}\text { Records from } \\
\text { Lakshadweep }\end{array}$ & References \\
\hline 22. & Tridacna squamosa Lamarck, 1819 & $\begin{array}{l}\text { Fluted Giant } \\
\text { Clam }\end{array}$ & Schedule I & $\begin{array}{l}\text { Agatti, Bangaram, Bitra, } \\
\text { Chetlet }\end{array}$ & Appukuttan et al. (1989), Present study \\
\hline 23. & Hippopus hippopus (Linnaeus, 1758) & Bear Paw Clam & Schedule I & Not Recorded & \\
\hline 24. & $\begin{array}{l}\text { Class: Cephalopoda } \\
\text { Subclass: Nautiloidea } \\
\text { Order: Nautilida } \\
\text { Family: Nautilidae } \\
\text { Nautilus pompilius Linnaeus, } 1758\end{array}$ & $\begin{array}{l}\text { Chambered } \\
\text { Nautilus }\end{array}$ & Schedule I & Bitra & Ramadoss (2003), Present study \\
\hline
\end{tabular}

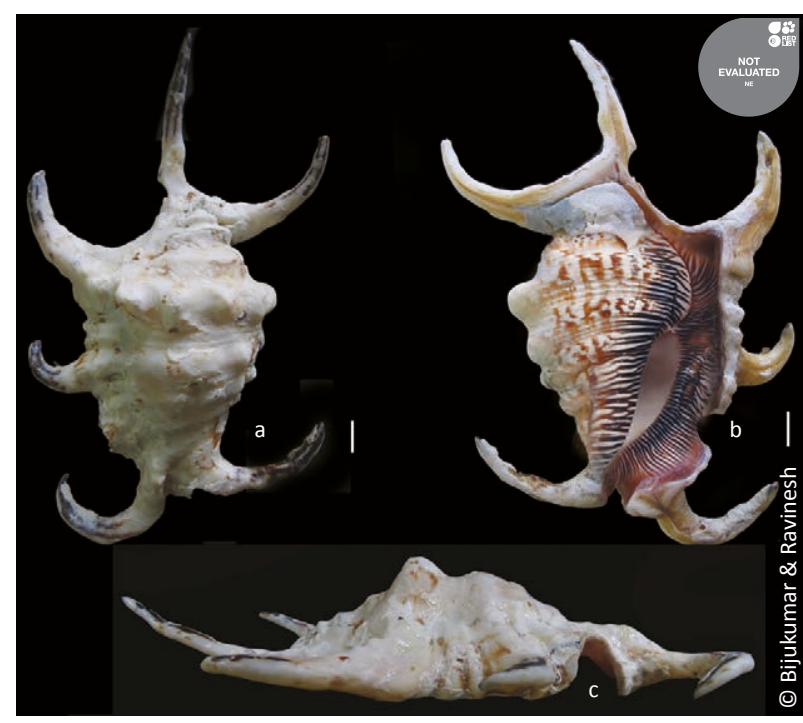

Image 2. Harpago arthriticus Röding

a - dorsal view; $b$ - ventral view; $c$ - lateral view $($ scale $=1 \mathrm{~cm})$

and spotted with brown, but is covered over by a dark brown periostracum. The interior of aperture is smooth and orange-red in colour. Operculum slightly curved, brown and its edges smooth.

Shell length: 105-160 mm.

Remarks: This species was recorded from Lakshadweep by Apte (2014). In the present study specimens were recorded from Minicoy, Kalpeni, and Kavaratti islands. Rare in occurrence. Specimens were observed at shallow tidal pools and lagoons, around 5-10 m depth. Included in Schedule IV of WPA. Not listed in CITES. Not evaluated in IUCN Red List of Threatened Species.

\section{Lambis truncata ([Lightfoot], 1786) (Images 4 a-i)}

Appukuttan et al. 1989, p.79; Venkataraman et al. 2012, p. 191; KSCSTE 2013, p. 146; Apte 2014, p. 59.

Description: Shells large and massive, ovate, with spire very obtuse and knotty. Four uppermost whorls are depressed, so as to give the spire a truncated appearance, and each of the other whorls have a row of strong rounded knobs. The ventral side of the shell

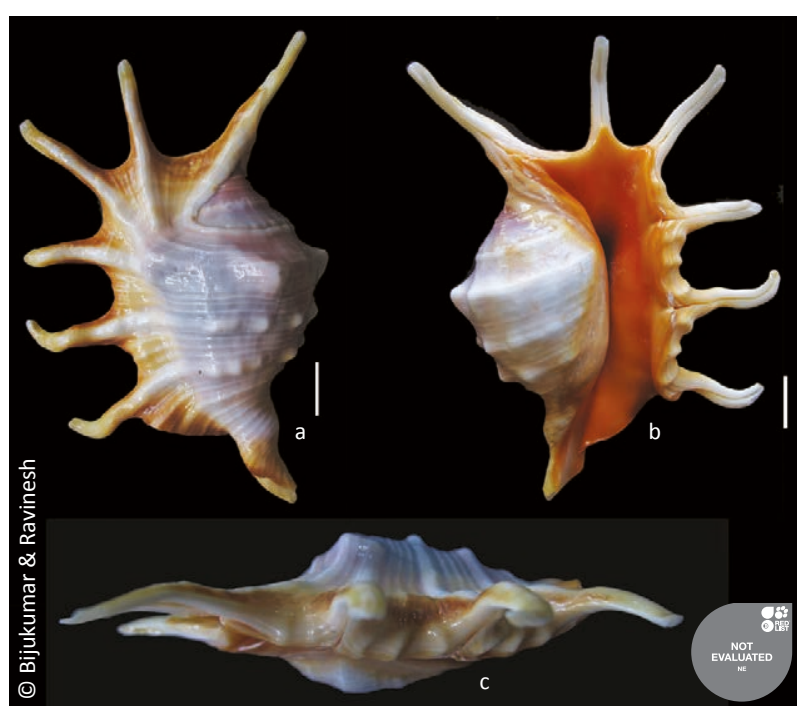

Image 3. Lambis crocata Link

a - dorsal view; b - ventral view; $c$ - lateral view $($ scale $=1 \mathrm{~cm}$ )

is extensively glazed. Columella and the outer lip of the aperture is nearly smooth. Outer lip with a well-marked stromboid notch and six slender, hollow digitations. Inner lip with a heavy, extensive callus covering most of the ventral side of the body whorl and spire, including sometimes the apex in mature specimens. Siphonal canal forming a wide and moderately developed digitation anteriorly slightly bent towards the right (Image 4f). Operculum brown, chitinous, elongate and slightly curved. Outside of shell cream, sometimes with spare light brown to tan speckles. Aperture white deep inside, outer lip and ventral callus creamy pink, sometimes becoming purplish towards the edges of the glazed area.

In L. truncata the juvenile shells are long, with a thin outer lip, which is free from claws (Images 4 a,b). In later stages the outer lip flares up (Images $4 \mathrm{c}, \mathrm{d}$ ) and then develops digitations (Images $4 \mathrm{e}, \mathrm{f}$ ). In adults the outer lips become thicker and slightly curve outwards in later stages (Images $4 \mathrm{~h}, \mathrm{i}$ ). Juveniles are easily distinguishable as the apex is flat, hence the name truncata.

Shell length: 320-380 mm. 


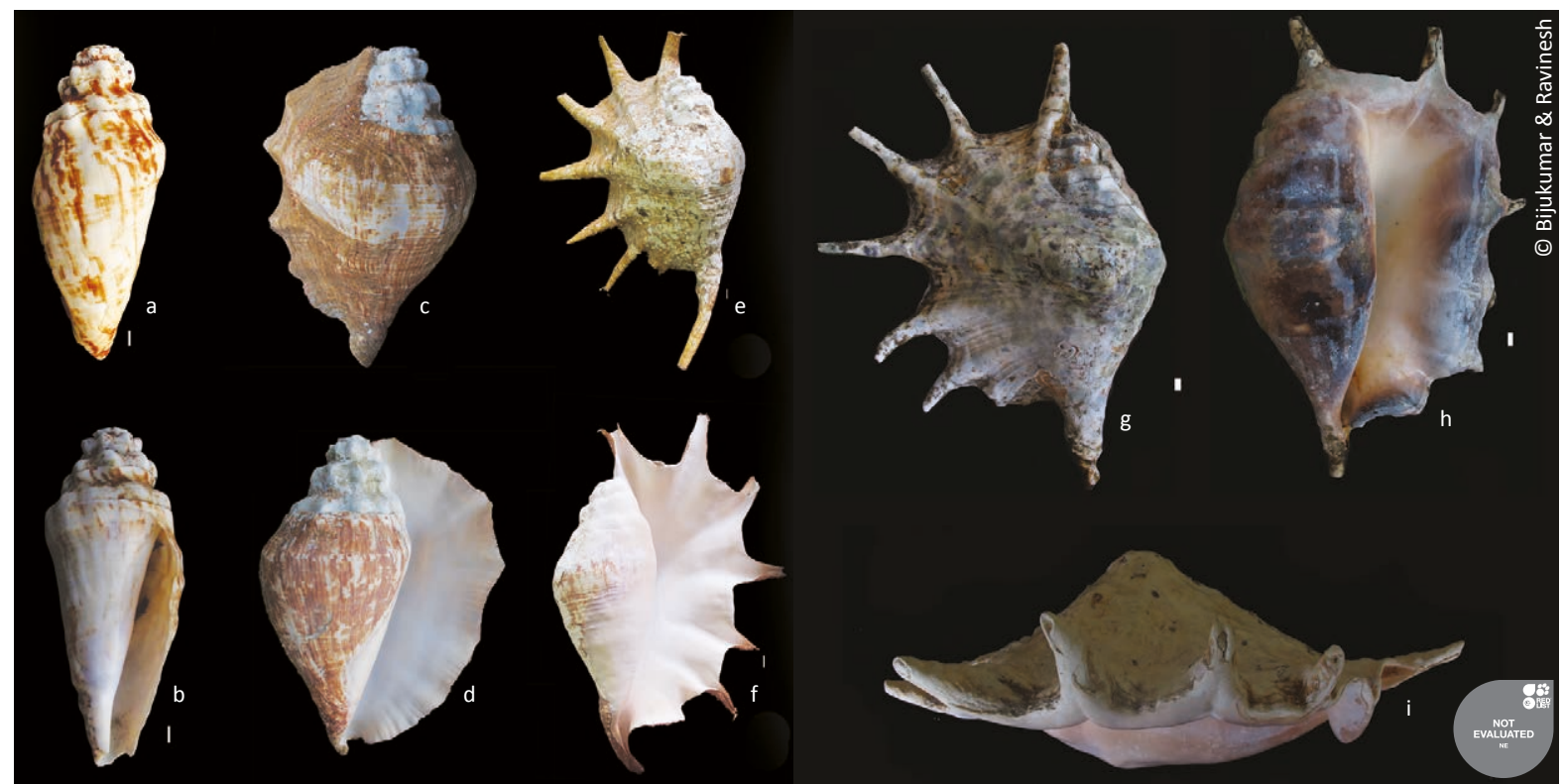

Image 4. Lambis truncata Lightfoot a-f - various life stages; $g$ - dorsal view of adult shell; $h$ - ventral view of adult shell; $i$ - lateral view of adult shell (scale $=1 \mathrm{~cm}$ )

Remarks: This species was recorded only from the shallow waters around all the inhabited islands of Lakshadweep (Appukuttan et al. 1989; KSCSTE 2013; Apte 2014). Common in appearance. They were found in areas with sandy bottom. Included in Schedule IV of WPA. Not listed in CITES. Not evaluated in IUCN Red List of Threatened Species.

\section{Lambis indomaris Abbott, 1961(Images 5 a-c)}

Rao 2003, p. 149; Apte, 2014, p. 60

Description: Shell ovate, tuberculated, and transversely striated, with six knobbed labial digitations and a long slender knobbed siphonal digitation, which is strongly curved to the right. The lobe on the left side of the first digitation is either very much reduced or bent back around the apex of the shell. Digitations 4, 5 and 6 are more stunted. Whorls 9-11. Siphonal canal long, strongly curved to the right and bearing 4-5 weak knobs. Aperture rather narrow, quadrate and deep within its solid purple.

Shell greyish-white colour, slightly mottled with brown; throat saffron-coloured, and both the lips are purplish. Inside of outer lip with numerous crowded, white, slightly raised spiral lirae which end before they reach the broad, smooth yellow orange edge of the outer lip. Columella and parietal wall brownish-purple and overlaid with about 30-40 white to tan white, raised spiral lirae. Operculum long, slightly curved, light brown, with 10 small serrations.

Shell length: 90-135 mm.

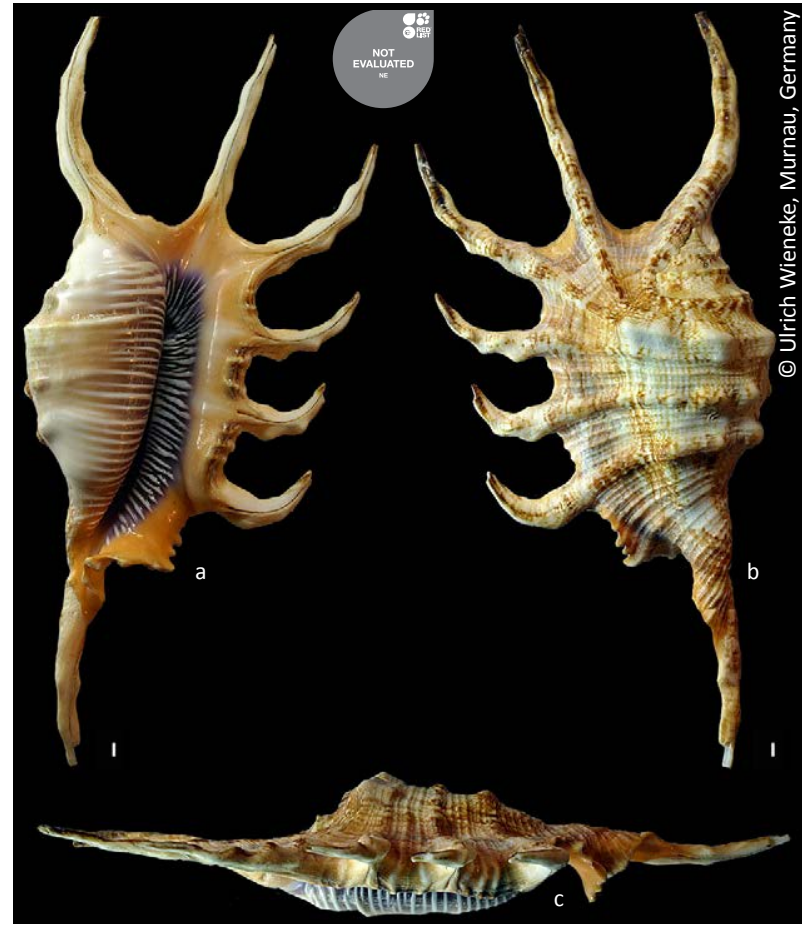

Image 5. Lambis indomaris Abott

a - ventral view; $b$ - dorsal view; $c$ - lateral view $($ scale $=1 \mathrm{~cm})$

Remarks: Rao (2003) and Apte (2014) recorded this species from Lakshadweep, though the exact locality was not mentioned. We have not found this species from any of the islands and it may be assumed that it is very rare in occurrence in these islands. The population status of the species needs to be studied in Lakshadweep. 
Included in Schedule IV of WPA and not listed in CITES. Not evaluated by IUCN Red List of Threatened Species, either.

\section{Cassis cornuta (Linnaeus, 1758) (Images 6 a-c)}

Rao \& Rao 1991, p. 277; Rao 2003, p. 201; Venkataraman et al. 2012, p. 197; KSCSTE 2013, p. 144; Apte, 2014, p. 87.

Description: Shell very solid, heavy, rotund, with large horn-like knobs and a wide flat base. Last whorl with 3 or 4 spiral rows of large tubercles, those at shoulder being much longer and stouter than the others. Outer surface of whorls finely pitted, from numerous intersecting axial and spiral threads. Aperture long and narrow, heavily calloused. Outer lip thickened in a broad and flat shelf, with a dorsally recurved outer edge and with 5-7 strong teeth on its inner edge. Inner lip with an extensive callous shield, forming a flange along left side of body whorl, and produced over the spire to join the outer lip at its posterior end. Columella with irregular spiral ridges. Operculum elongate-ovate, about onefourth the length of aperture.

Dorsal side and spire greyish-white, often somewhat spotted with light brown. Calloused ventral side glossy cream or orange, with two spiral rows of brown spots in the central region. Teeth and ridges of the aperture white. Outer lip with 6 or 7 broad patches of brown on its dorsal side and outer edge.

\section{Shell length: $50-410 \mathrm{~mm}$.}

Remarks: Also known as "King Shell", this largest of the helmet shells was recorded from the waters around Minicoy, Kalpeni, Androth and Bangaram islands of Lakshadweep (Rao \& Rao 1991; Rao 2003; Venkataraman et al. 2012; KSCSTE 2013; Apte 2014).

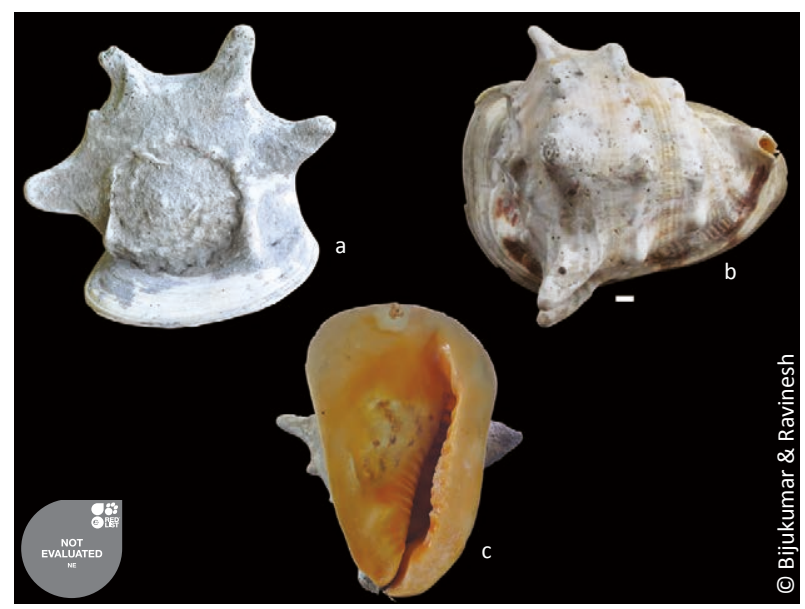

Image 6. Cassis cornuta Linnaeus

a - spire; b - dorsal view; c - ventral view $($ scale $=1 \mathrm{~cm})$
Included in Schedule I of WPA of India. Not listed in CITES. Not evaluated in IUCN red list. This species plays an important ecosystem function in the islands as the predator of crown-of-thorns starfish (Acanthaster planci), which feeds on corals (Poutiers 1998).

\section{Cypraecassis rufa (Linnaeus, 1758) (Images 7 a-d)}

Rao \& Rao 1991, p. 277; Rao 2003, p. 202; Venkataraman et al. 2012, p. 197; KSCSTE 2013, p 146;Apte 2014, p. 88.

Description: Shell thick and heavy, ovate with a strongly callous apertural side. Spire short, with channelled sutures and fine nodulose spiral ribs, but lacking axial varices. Body whorl with rounded shoulder, 3 or 4 spiral rows of rounded knobs posteriorly, two spiral rows of axial ridges anteriorly, and with 2 or 3 nodulose axial riblets between them. Knobs at shoulder not longer and stouter than the others. Aperture long and narrow, with an oblique furrow at posterior end. Outer lip very thick, produced over the spire, with strong teeth along the inner edge. Inner lip strongly lirate, with an extensive, thick and convex callous shield. Columellar margin with an axial swelling bearing strong teeth. Operculum circular to oval, small, with concentric growth lines, about one-tenth the length of aperture.

Dorsal side and spire orange-brown or reddish, mottled and blotched with dark and light brown and grey. Callous ventral side glossy, creamy orange, becoming deep red around and inside the aperture, and stained with dark brown between the ridges of the inner lip. Teeth and ridges of the aperture whitish.

Remarks: This species was recorded from the shallow coastal waters of Minicoy, Kalpeni, Androth, Bangaram, and Chetlet islands (Rao \& Rao 1991; Rao, 2003;

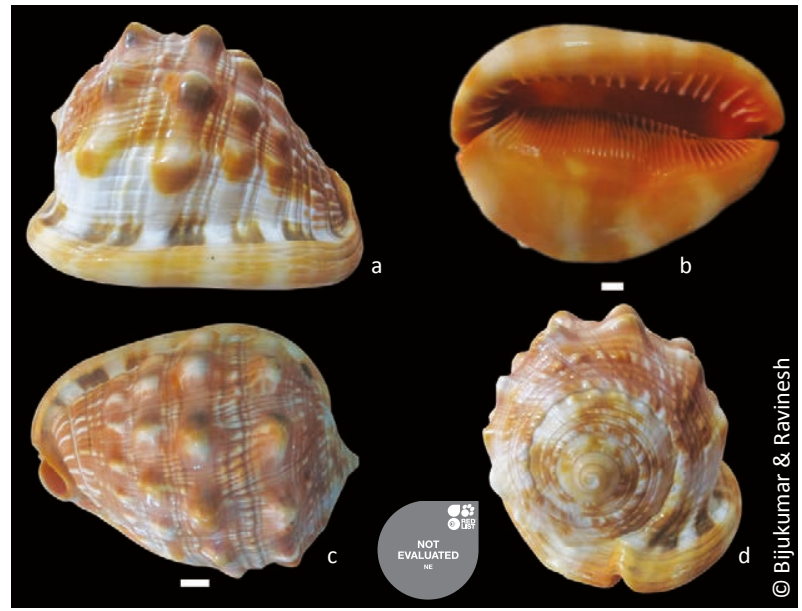

Image 7. Cypraecassis rufa Linnaeus

a - lateral view; b - ventral view; c - dorsal view; $d$ - spire $($ scale $=1 \mathrm{~cm})$ 
Venkataraman et al. 2012; KSCSTE 2013; Apte 2014). Included in Schedule I of WPA. Not listed in CITES. Not evaluated in IUCN Red List of Threatened Species.

\section{Charonia tritonis (Linnaeus, 1758) (Images $8 \mathrm{a}, \mathrm{b}$ )} Rao \& Rao 1991, p. 278; Ramakrishna \& Dey 2003, p. 19; Rao 2003, p. 206; KSCSTE 2013,p. 144; Apte 2014, p. 91.

Description: Spire very tall, occupying more than one-third of the total length. Broad bodywhorl with two prominent varices. Deeply grooved flattened spinal spiral ribs and occasional fine extra ribs below. Aperture broader, bordered by the reflexed margin of inner lip bearing many plaits and by the outer lip having a wavy margin. Shell creamy pink with reddish or dark brown crescents and patches. Aperture orange brown with white channels between teeth on outer lip.

Shell length: 390-450 mm.

Remarks: Recorded earlier from Agatti, Amini, Chetlet, and Kalpeni islands (Rao \& Rao 1991; Rao 2003; Ramakrishna \& Dey 2003, KSCSTE 2013; Apte 2014), this species is found among shallow coral seas and on sandy bottoms. As a well-known predator of the crown-of-thorns starfish, it has a critical role in coral reef ecosystem. During the present survey none of the specimens could be located. Over exploitation, especially for shell trade could be the reason for the decline of this species in Lakshadweep. Included in Schedule I of WPA. Not listed in CITES despite requests

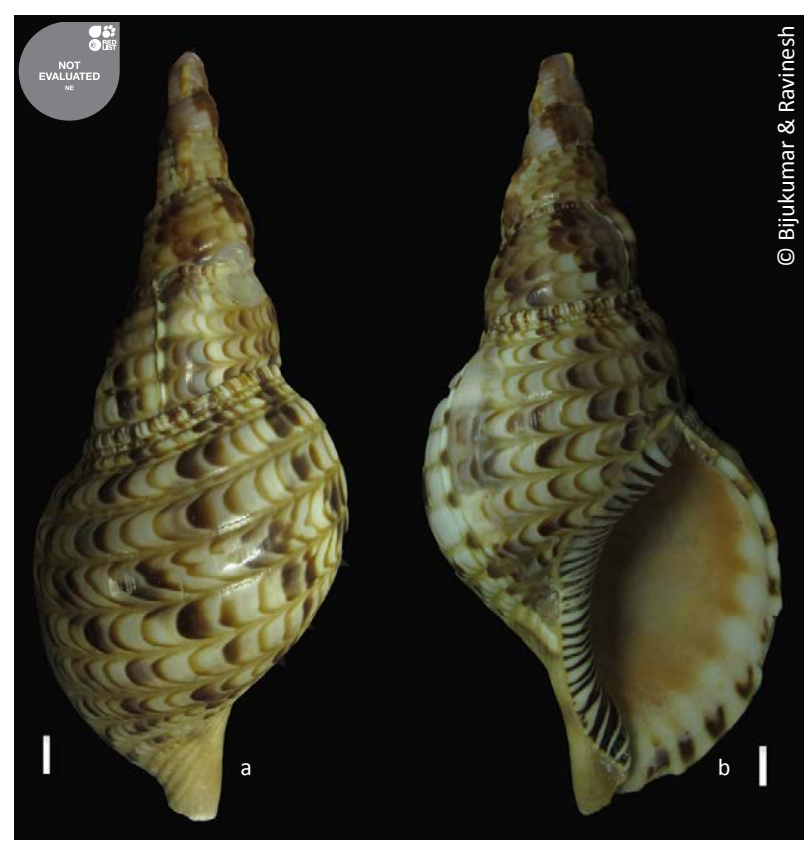

Image 8. Charonia tritonis Linnaeus a - dorsal view; b - ventral view (scale $=1 \mathrm{~cm})$ from some countries because of the absence of trade data. Not listed in IUCN Red List of Threatened Species . As the predator of crown-of-thorns Starfish (Acanthaster planci) which feeds on corals, this species plays a major ecosystem function in the islands (Poutiers 1998).

\section{Talparia talpa (Linnaeus, 1758) (Images $9 \mathrm{a}, \mathrm{b}$ )}

Rao \& Rao 1991, p. 277; Apte 1998, p. 23; Rao 2003, p. 174; KSCSTE 2013,p. 149; Apte 2014, p. 76.

Description: Shell large, solid, almost cylindrical in outline, with widely convex to nearly straight lateral margins and slightly produced anterior and posterior extremities. Dorsal side moderately swollen, without a mantle groove. Ventral side flat, rounded laterally, with a narrow, straight aperture which is only a little curved posteriorly. Apertural teeth numerous, short and fine. Teeth of inner lip not extending far into the aperture. Anterior longitudinal furrow of inner lip short and rather deep.

Colour pattern variable. The dorsal surface smooth and shiny, brown or yellowish-brown, with three or four yellow or light brown transverse bands. The margins, base and teeth completely dark brown or black; interstices of teeth stained with cream or white. In the living cowries mantle is greyish or black, with long cylindrical papillae.

Shell length: 80-110 mm.

Remarks: This species was earlier recorded from Kavaratti and Kalpeni islands (Rao \& Rao 1991; Apte 1998; Rao 2003; KSCSTE 2013; Apte 2014). Included in Schedule I of WPA. Not listed in CITES. Not listed in IUCN Red List of Threatened Species. During the study, one

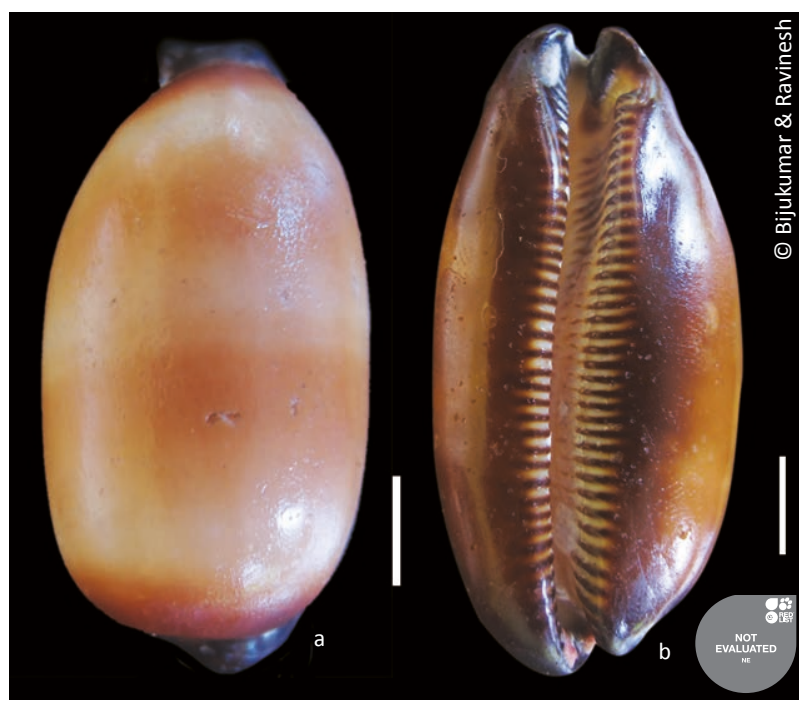

Image 9. Talparia talpa Linnaeus a - dorsal view; b - ventral view $($ scale $=1 \mathrm{~cm})$ 
specimen was recorded from Kalpeni. Detailed surveys are required for assessing the status of this species in Lakshadweep, as the collection of cowries is one of the major economic activities of the local population. Distinguishing this species from the other species is rather difficult in the field.

\section{Tudicla spirillus (Linnaeus, 1767) (Images $10 \mathrm{a}-\mathrm{c}$ )}

Description: Shell moderately solid, pyriform and with a long, sinuous, smooth siphonal canal. Nuclear whorls mammillate, projecting, swollen, pinkish or yellowish. Spire flat. Spiral sculpture of numerous, raised threads which are squarish and broad on the base of the whorls. Last whorl with a squarish periphery, bounded above by a sharp, wavy keel and below by a series of 6-8 round, low nodules. Aperture ovate-round, glossy, pinkish to purple within, and bounded on the outer side by a sharp lip. Inside of outer wall with numerous, fine, raised, spiral ridges. Parietal shield well-developed, smooth and glossy white. Posterior canal region with a swollen, button-like, white callus. Base of columella with a single, strong, spiral plica. Siphonal canal open along its length, long and slightly sinuous. Colour of shell shiny cream to pinkish grey with sparse flecks of light-brown.

Shell length: 70-85 mm.

Remarks: The present study records this species for the first time from Kalpeni and Bitra islands of Lakshadweep. The recorded two specimens were observed on sandy bottom. Further surveys are required to assess the population status of this species included in schedule IV of WPA. Not in CITES and IUCN Red List of

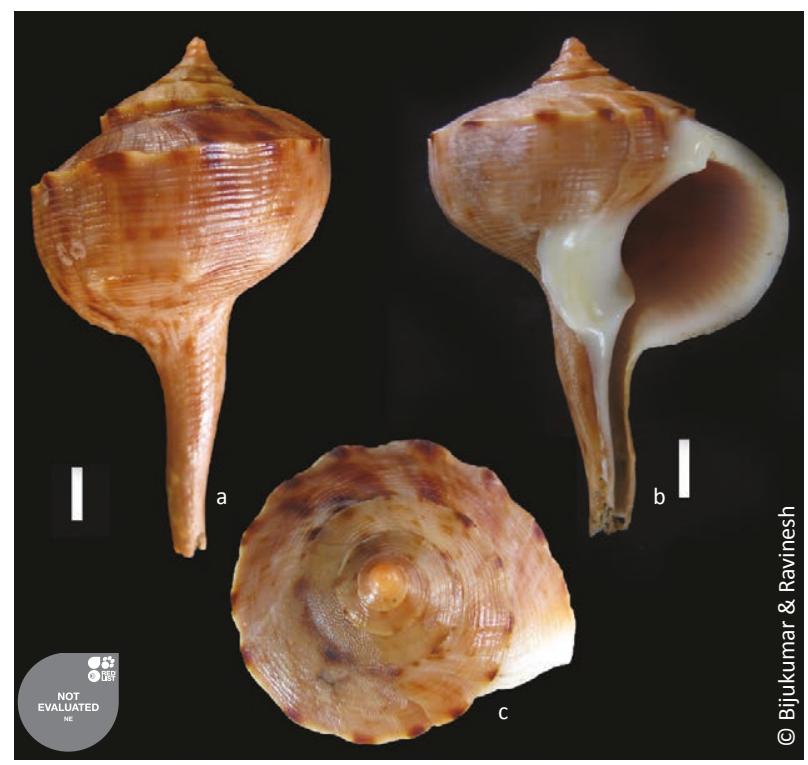

Image 10. Tudicla spirillus (Linnaeus)

a - dorsal view; $\mathrm{b}$ - ventral view; $\mathrm{c}$ - spire $($ scale $=1 \mathrm{~cm})$
Threatened Species.

11. Placuna placenta (Linnaeus, 1758) (Images 11 a-c)

Description: Asymmetrical with a characteristically flat, thin, translucent shell. The valves form an orbicular outline, which is compressed laterally; the right valve is almost flat while the left is weakly convex. Outer shell surface marked by projecting imbricate lamellae. Inner shell surface smooth and polished. Generally translucent and colourless, growing more opaque and white with age.

Shell length: $120 \mathrm{~mm}$.

Remarks: The present study marks the record of this species for the first time from Kavaratti Island of Lakshadweep. One specimen was observed on sandy bottom. Further surveys are required to assess the population status of this species included in schedule IV of WPA. Not in CITES and IUCN Red List of Threatened Species.

\section{Tridacna maxima (Röding, 1798) (Images 12 a-c)}

Rao \& Rao 1991, p. 286; KSCSTE 2013,p. 150

Description: Valves heavy and thick. Valve margins undulate with about five generally sharply triangular extremities of rib interstices. Hinge line less than half of shell length. Inequilateral valves are elongate to shortobtuse-triangular. Raised external valve sculpture. Large byssal opening. Greyish-white shell tinted with yellow or pinkish-orange. Bright blue, green or brown coloured mantle conceals the distinctively furrowed edges of shell.

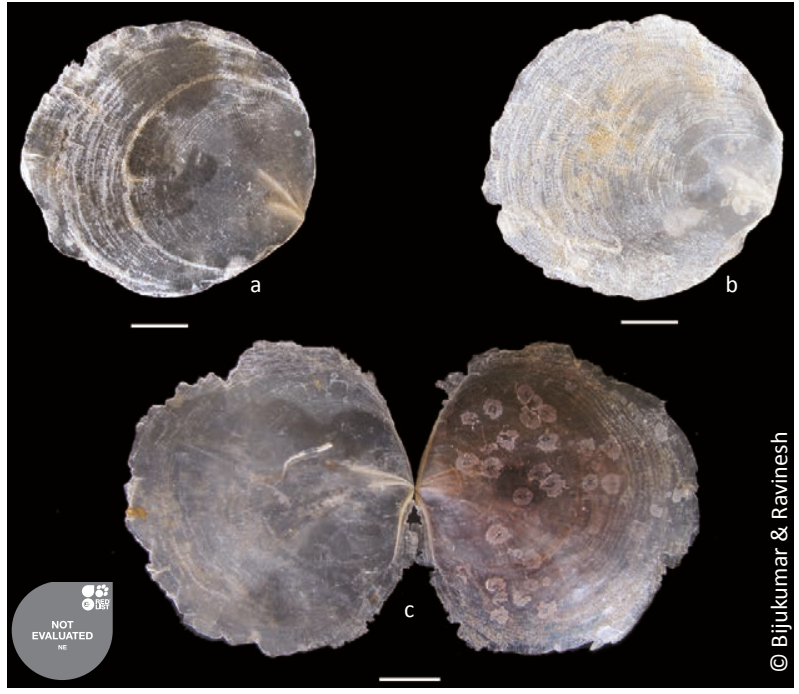

Image 11. Placuna placenta Linnaeus

a - dorsal shell; b- ventral shell; c- dorsal view of both shells opened (scale $=1 \mathrm{~cm})$ 

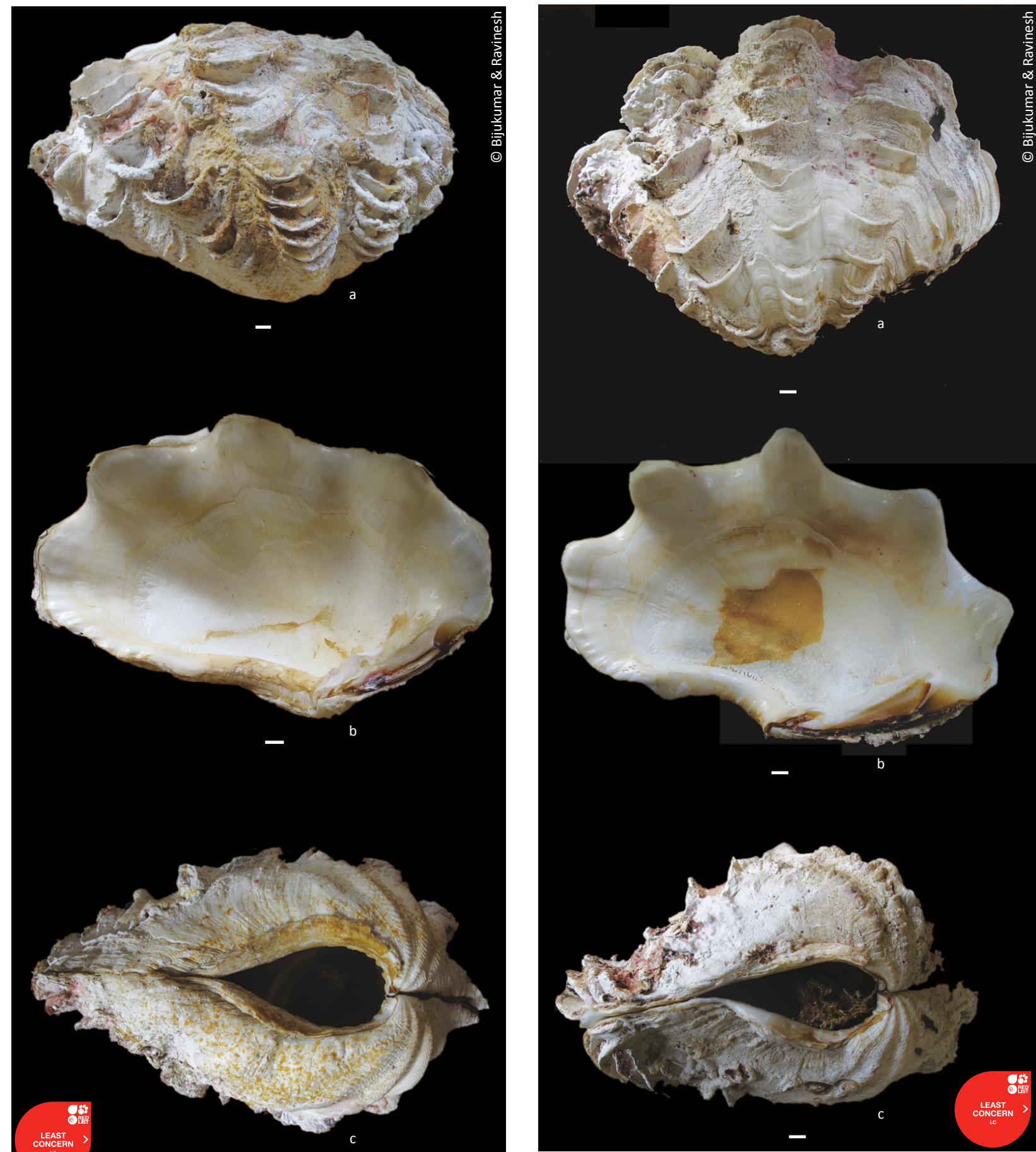

89
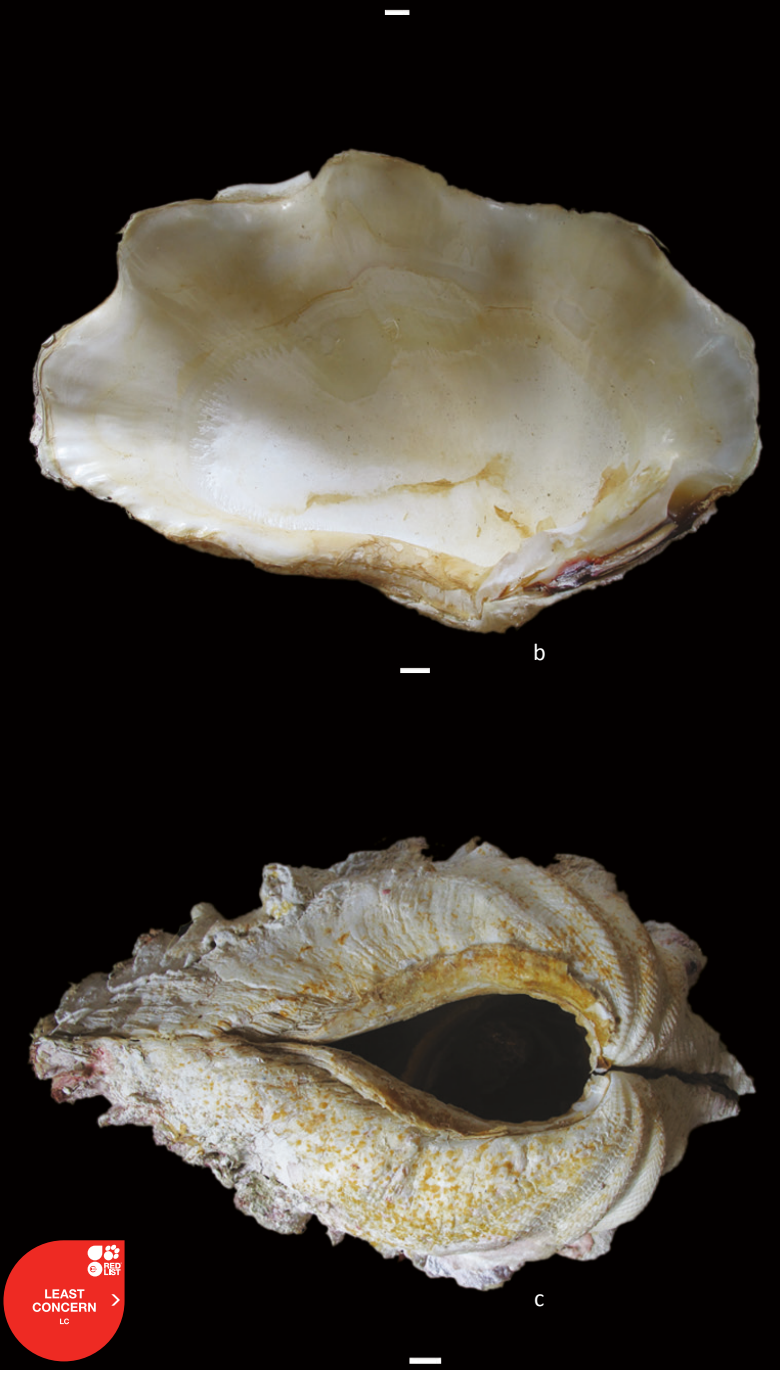

Image 13. Tridacna squamosa Lamarck

a - exterior of right valve; b - interior of left valve; c - ventral view showing byssal orifice $($ scale $=1 \mathrm{~cm})$

a - exterior of right valve; $b$ - interior of left valve; c - ventral view showing byssal orifice $($ scale $=1 \mathrm{~cm})$

Shell length: 250-350mm.

Remarks: It is one of the widespread scheduled species recorded from almost all the islands of Lakshadweep (Rao \& Rao 1991; KSCSTE 2013). Apte (2013) reported on the ecology, population dynamics

and conservation of $T$. maxima in the Lakshadweep Archipelago. Also known by the name 'Small Giant Clam', this species grows on rocks and crevices of coral reefs, usually attached by the byssus threads. Included in schedule I of WPA. Not listed in CITES. Listed as 'Lower Risk' in the IUCN Red List of Threatened Species 
(IUCN, 2013).

\section{Tridacna squamosa Lamarck, 1819 (Images 13 a-c)}

Appukuttan et al. 1989, p. 83.

Description: Valves moderately thick and heavy. Shell equilateral. Dorsal margin fan-shaped in outline. Valve margins undulate with 4-6 pointed to bluntly rounded, crenulated extremities of rib interstices. Hinge line half of shell length. Characteristic broad leaf-like projecting scales on primary folds of ribs. Small to medium sized byssal opening.

Colour of shell tan or grey but new growth is often white. Mantle colour patterns quite variable, brown, green, blue or purple coloured with large irregular blotches.

Shell length: 300-400 mm.

Remarks: Commonly referred to as scaly clam, fluted clam or giant clam, this species was recorded from the Agatti, Bangaram, Bitra, and Chetlet islands by Appukuttan et al. (1989). We recorded this species from Kavaratti Island. Detailed field surveys are required to relocate the populations around the various islands of Lakshadweep. Included in Schedule I of WPA. Not listed in CITES. Listed as 'Lower Risk' in the IUCN Red List of Threatened Species (IUCN 2013).

\section{Nautilus pompilius Linnaeus, 1758 (Images $14 \mathrm{a}, \mathrm{b}$ )} Ramadoss 2003, p.207.

Description: Large and thick shell, with smooth surface, polished and marked by reddish-brown wavy lines against creamy background. Parietal wall of aperture black. Shell spirally coiled and partitioned internally into a series of gas-filled flotation chambers. The animal lives in the large external shell. Below the hood protrudes about 90 small suckerless tentacles. Beneath, there is a funnel containing two separate lobes.

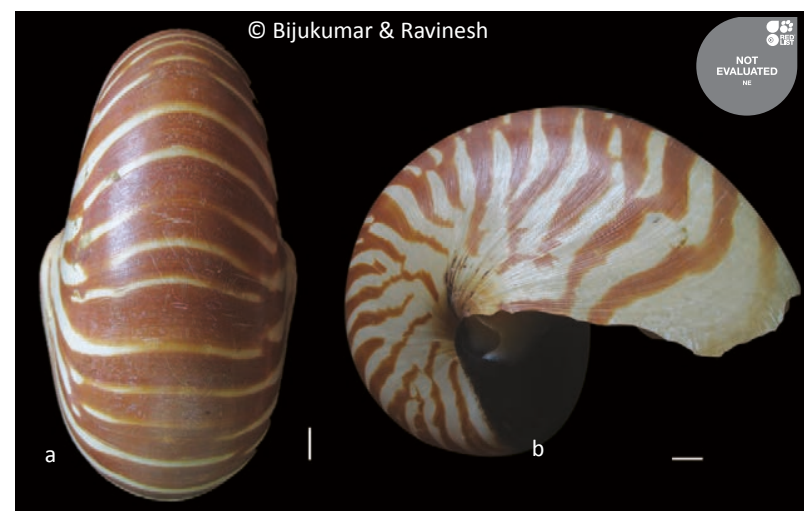

Image 14. Nautilus pompilius Linnaeus

a - dorsal view of shell; b - lateral view of shell (scale $1 \mathrm{~cm}$ )
Shell length: $200 \mathrm{~mm}$

Remarks: This species is distributed in the Indo-West Pacific; the Philippines, via Indonesia and New Guinea to Fiji; north-eastern and north-western Australia. In India this species is reported only from Andaman and Nicobar islands. During the present study one dead specimen was recorded from Bitra Island, from a coral rock bottom. More research is warranted to establish whether this species actually lives around these islands.

\section{CONSERVATION}

The threats to biodiversity of Lakshadweep, as summarized in the National Biodiversity Strategy and Action Plan (NBSAP), can be due to: (i) the fragility of the island ecosystem, (ii) the imposing of locally unsuitable development programmes which jeopardize the economy and ecology of the islands, and (iii) the lack of knowledge about what was there creates a lacuna in understanding the depth of biodiversity loss (MoEF \& Kalpavriksh 2004). As a coral island ecosystem, the entire biological diversity is primarily dependent on corals. The pressure on the ecosystem as well as biodiversity at present is mainly of anthropogenic origin. Global environmental issues such as climate change and the pressure created by increasing human population and demand for natural resources create a host of threats to the sensitive atoll islands, lagoon and the surrounding open ocean (KSCSTE 2013). Elevated Sea Surface Temperatures (SSTs) caused by El Nino Southern Oscillation (ENSO) and climate change have already reported to affect the health of the coral reef ecosystem in some islands (Arthur 2000).

Despite the fact that marine molluscs represent an estimated $23 \%$ of all extant marine taxa, conservation of marine molluscs remains neglected globally and often information regarding the status of commercially exploited marine molluscs has been overshadowed by the collapse of finfish fishery (McManus 1997). Research into the conservation status of molluscs has so far failed to reflect this importance, with minimal inclusion on the Red List of World Conservation Union (IUCN) (Peters et al. 2013). Inclusion of 24 species of marine molluscs under various schedules of the WPA notwithstanding, the research and conservation on these species received little attention in policy documents. A majority of the molluscs listed in various schedules of WPA of India are preferred items in shell trade markets. High market demand, coupled with a lack of awareness and inadequate enforcement were found to be the major 
driving forces behind the illegal marine curio trade (John et al. 2012).

A lack of quantitative data on abundance of species, ranges, habitat requirements, dispersal, and connectivity among populations (Chapman 1999) remains the major handicap in assessing the conservation status of species listed in various schedules of WPA. For example, the extirpation of Giant Triton Charonia tritonis in the IndoPacific has been attributed to over harvesting (Moore \& Ndobe 2008). Although there is no organised shell trade at present in Lakshadweep, many of the species are collected for food. Further, the developmental stages of scheduled molluscs such Harpago chiragra, $H$. arthritica and Lambis spp. are often difficult to identify in the field, which indirectly facilitate indiscriminate collection of these species. Many species of Strombidae, to which the genera Harpago and Lambis belong, are eaten, and sometimes an important source of protein. This also reiterates the need for creating more awareness among the islanders regarding the scheduled species of molluscs. A poster on sea shells of Lakshadweep protected under various schedules of Wildlife (Protection) Act of India has been prepared for creating awareness (Appendix 1).

According to Peters et al. (2013) research is needed to assess the threat from rare shell collecting towards mollusc population decline to determine what measures should be taken to enable this activity to continue sustainably while at the same time allowing for the protection of vulnerable species. While Indian WPA prevents collection of animals included in various schedules, research priority should also focus on other molluscs such as cowries and octopuses which are currently collected in large numbers. According to Apte et al. (2010) ever increasing economic interactions between the densely populated island communities and the adjoining coral reefs of Lakshadweep can indirectly affect the scheduled Giant Clam (Tridaca spp.), rendering population monitoring imperative.

Islands are very sensitive ecosystems. Hence strategies should be adopted to integrate biodiversity into every developmental plan, especially in the context of rapid economic development of Lakshadweep. Preparation of people's biodiversity register for the island ecosystems, as envisaged in the Biological Diversity Act of India, would help in developing suitable management plans at the grass roots level. As each island is a separate entity in terms of its biodiversity and pressures on it, a separate management plan has to be developed for each island, with the help of local communities, giving due importance for the scheduled species and other heavily exploited species. The participation of local communities should also be ensured for planning and decision making with regard to biodiversity.

Currently, there are 31 MPAs in India represented under 33 national parks and sanctuaries, covering an area of 627,121ha. The only MPA in Lakshadweep is Piiti Wildlife Sanctuary (1ha), included in the category II (Venkataraman et al. 2013). In Andaman and Nicobar islands, however, there are 15 MPAs covering an area of 67,254 ha (about $11 \%$ of the total area of MPAs in India). Lakshadweep has many untouched and undisturbed pristine reefs like Suheli par with $78.96 \mathrm{~km}^{2}$ of lagoon area, Baliyapani par with $57.46 \mathrm{~km}^{2}$ of lagoon area, Cheriyapani par with $172.59 \mathrm{~km}^{2}$ of lagoon area and Perumul par with $83.02 \mathrm{~km}^{2}$ of lagoon area, which remains to be studied fully for realising the magnitude of biodiversity. While in the Indian context MPAs are not a specific legal category, national parks, sanctuaries and community conservation reserves declared either in selected biodiverse islands or declaration of a biosphere reserve covering the whole Lakshadweep Archipelago is strongly recommended for conservation and sustainable management of biodiversity for future generations.

\section{REFERENCES}

Aditi, N. \& D.A. Apte (2013). Artisanal octopus fishery: socioeconomics and management, pp 409-418. In: Venkataraman, K., C. Sivaperuman \& C. Raghunathan (eds). Ecology and Conservation of Tropical Marine Faunal Communities. Springer Berlin Heidelberg, 481pp.

Appukuttan, K.K., A. Chellam, A., K. Ramdoss, A.C.C. Victor \& M.M Meiyappan (1989). Molluscan resources, pp. 77-92. In: Suseelan, C. (ed.). Marine Living Resources of the Union Territory of Lakshadweep: An Indicative Survey with Suggestions for Development. Bulletin, 43 Central Marine Fisheries Research Institute, Kochi, Kerala, 256pp.

Apte, D.A. (1998). The Book of Indian Shells. Oxford University Press, Mumbai, $115 \mathrm{pp}$.

Apte, D.A. (2009). Opisthobranch fauna of Lakshadweep Islands, India with 52 new records to Lakshadweep and 40 new records to India. Part 1. Journal of the Bombay Natural History Society 106: 162-175.

Apte, D.A. (2012a). Field Guide to the Marine Life of India $-1^{\text {st }}$ Edition. Stusa Mudra Private Limited Mumbai, 502pp.

Apte, D.A. (2012b). Ecology, population dynamics and conservation of the Giant Clam Tridacna maxima (Röding, 1798) in the Lakshadweep Archipelago. PhD Thesis, University of Mumbai, 183pp.

Apte, D.A. (2014). Sea Shells of India. An Illustrated Guide to Common Gastropods. Bombay Natural History Society \& Oxford University Press, Mumbai, 197pp.

Apte, D.A. \& D. Sutirtha (2010). Ecological determinants and stochastic fluctuations of Tridacna maxima survival rate in Lakshadweep Archipelago. Systematic and Biodiversity 8(4): 461-469; http:// dx.doi.org/10.1080/14772000.2010.537393

Apte, D.A., D. Sutirtha \& K.K. Idreesbabu (2010). Monitoring densities of the Giant Clam Tridacna maxima in the Lakshadweep Archipelago. Marine Biodiversity Records 3: e78 1-9; http://dx.doi.org/10.1017/ S1755267210000680

Apte, D.A., K.K. Idreesbabu \& D. Sutirtha (2012). Density estimation of Tridacna maxima in Lakshadweep Archipelago, pp. 147-154. In: Bhatt, J.R., J.K.P. Edward, D.J. Macintosh \& B.P. Nilaratna (eds.). 
Coral Reefs of India - Status, Threats and Conservation Measures. IUCN, 305pp.

Apte, D.A. \& B. Vishal (2014). New records of opisthobranchs from Lakshadweep, India (Mollusca: Heterobranchia). Journal of Threatened Taxa 6(3): 5562-5568; http://dx.doi.org/10.11609/ JoTT.03487.5562-8.

Apte, D.A., A. Kulkarni \& D. Sutirtha (2014). Giant Clam Tridacna maxima from Lakshadweep Archipelago, India: Understanding Population Ecology. LAP Lambert Academic Publishing, Germany, 308pp.

Arthur, R. (2000). Coral bleaching and mortality in three Indian reef regions during an El Niño southern oscillation event. Current Science, 79: 1723-1729.

Chapman, M.G. (1999). Are there adequate data to assess how well theories of rarity apply to marine invertebrates? Biodiversity and Conservation 8: 1295-1318; http://dx.doi.org/ 10.1023/A:1008909323840

Chapmann, A.D. (2009). Numbers of Living Species in Australia and the World http://www.environment.gov.au/node/13876

da Fonseca, G.A.B., R.A. Mittermeier \& C.G. Mittermeier (2006). Conservation of Island Biodiversity: Importance, Challenges and Opportunities. Centre for Applied Biodiversity Science. Conservation International, Arlington, $16 \mathrm{pp}$.

IUCN (2013). IUCN Red List of Threatened Species.Version 2013.2.<www.iucnredlist.org>. Downloaded on 09 May 2014.

John, S., M.P.K. Batu, S. Kuppusamy \& B.C. Choudhury (2012) An assessment of legally protected marine fauna in Curio trade - a market study from Tamil Nadu, India. International Journal of Conservation Science 3: 217-230.

KSCSTE (2013). State of Environment Report for Lakshadweep. Kerala State Council for Science, Technology and Environment, Thiruvananthapuram, Kerala, 400pp.

Kunte, K. (2008). Competition and species diversity: removal of dominant species increases diversity in Costa Rican butterfly communities. Oikos 117: 69-76.

McManus, J.W. (1997). Tropical marine fisheries and the future of coral reefs: A brief review with emphasis on Southeast Asia. Coral Reefs 16: S121-S127; http://dx.doi.org/10.1007/s003380050248

MOEF \& Kalpavriksh (2004). National Biodiversity Strategy and Action Plan, India: Final Technical Report of the UNDP/GEF Sponsored Project.Ministry of Environment and Forests, Government of India and Kalpavriksh, New Delhi/Pune.

Mohamed, K.S. (2012). Marine mollusc diversity in India- Exploitation and conservation challenges in the $21^{\text {st }}$ century, pp. 37-64. In: Ramachandran, A. \& A. Joseph (eds.). Marine Biodiversity: Status, Opportunities and Challenges. Department of Marine Biology, Microbiology and Biochemistry, Cochin University of Science and Technology, Kerala.

Moore, A. \& S. Ndobe (2008). Reefs at risk in Central Sulawesi, Indonesia - status and Outlook. Proceedings of the 11th International Coral Reef Symposium, Ft. Lauderdale, Florida, 7-11 July 2008, pp. 840-844.

Namboodiri, P.N. \& P. Sivadas (1979). Zonation of molluscan assemblage at Kavaratti Atoll (Lacccadives). Mahasagar 12 (2): 239 246.

Olson, D.M. \& E. Dinerstein (1998). The global 200: A representation approach to conserving Earth's most biologically valuable ecoregions. Conservation Biology 12: 502-515.

Peters, H., B.C. O'Leary, J.P. Hawkins, K.E. Carpenter \& C.M. Roberts (2013). Conus: First comprehensive conservation red list assessment of a marine gastropod mollusc Genus. PLOS ONE 8(12): e83353; http://dx.doi.org/10.1371/journal.pone.0083353
Poutiers, J.M. (1998). Gastropods, pp. 363-648. In: Carpenter, K.E. \& V.H. Niem (ed.). FAO Species Identification Guide for Fishery Purposes. The Living Marine Resources of the Western Central Pacific. Volume 1. Seaweeds, corals, bivalves, and gastropods. Rome, FAO.

Prabhakaran, M.P., P.R. Jayachandran \& S. Bijoynandan (2012). New record of Scapharca cornea (Bivalvia: Pteriomorpha: Arcidae) from Minicoy Lagoon, Lakshadweep, India. Current Science 102 (11): 1516- 1518.

Prashanth, M. \& K. Veenakumari (1996). Nomenclature, classification and the basis of Schedules in the India Wildlife (Protection) Act, 1972. Current Science 70: 428-432.

Ramadoss, K. (2003). Gastropods pp. 202-210. In: Joseph M. \& A.A. Jayaprakash (ed.). Status Of Exploited Marine Fishery Resources of India. Central Marine Fisheries Research Institute, Kochi, Kerala, 308pp.

Ramakrishna \& A. Dey (2003). Manual on Identification of Scheduled Molluscs from India. Zoological Survey of India, Kolkata, 399pp.

Ramakrishna \& A. Dey (2010). Annotated checklist of Indian marine molluscs (Cephalopoda, Bivalvia, Scaphopoda) Part I. Zoological Survey of India, Kolkata, 357pp.

Rao, K.V. \& N.V. Rao (1991). Mollusca, pp. 273-362. In: Ghosh, A.K. \& A. Kumar (eds.). State Fauna Series 2, Fauna of Lakshadweep. Zoological Survey of India, Kolkata, 413pp.

Rao, N.V. (2003). Indian Sea Shells (Part I). Polyplacophora and Gastropoda. Zoological Survey of India, Kolkata, 416pp.

Ravinesh, R., B.K. Snehachandran \& A. Bijukumar (2013). Record of the Dendrodorid Slug, Dendrodoris coronata (Nudibranchia: Dendrodorididae) from Western Indian Ocean. Marine Biodiversity Records 6: e116; http://dx.doi.org/10.1017/S1755267213000894

Susan, V.D., N.G.K. Pillai \& P. Satheeshkumar (2012). A checklist and spatial distribution of molluscan fauna in Minicoy Island, Lakshadweep, India. World Journal of Fish and Marine Sciences 4 (5): 449-453. www.idosi.org/wjfms/wjfms4(5)12/4.pdf

Tripathy, B. \& A.K. Mukhopadhyay (2015). Marine molluscan diversity in India, pp. 39-74. In: Venkataraman, K. \& C. Sivaperuman (eds.). Marine Faunal Diversity in India: Taxonomy, Ecology and Conservation. Academic Press, London.

Venkataraman, K., R. Rajan, C.H. Satyanarayana, C. Raghunathan \& C. Venkatraman (2012). Marine Ecosystems and Marine Protected Areas of India. Zoological Survey of India, Kolkata, 296pp.

Venkataraman, K. \& M. Wafar (2005). Coastal and marine biodiversity of India. Indian Journal of Marine Sciences 34 (1): 57-75.

Vishal, B. \& D. Apte (2013). Current status of Indian opisthobranch fauna, pp. 63-79. In: Venkataraman, K., C. Sivaperuman \& C. Raghunathan (eds). Ecology and Conservation of Tropical Marine Faunal Communities. Springer-Verlag Berlin Heidelberg, 481pp.

Author Details: DR. A. BIJUkUmaR is the Associate Professor and Head of the Department of Aquatic Biology and Fisheries, University of Kerala and is specialized in taxonomy and biodiversity documentation. MR. R. RAVINESH and Ms. A.R. ARATHI are research scholars working in Department of Aquatic Biology and Fisheries, University of Kerala and pursuing their doctoral work on molluscan fauna of Lakshadweep and bivalves of west coast of India and Lakshadweep respectively. DR. K.K. IDREESBABU is the Scientist, working with Department of Science and Technology, Kavaratti, Union Territory of Lakshadweep.

Author Contribution: ABK was the Principal Investigator of the project and was involved in taxonomic identification and preparation of the paper. RR, ARA and KKI carried out field work in all the islands, identified the species in collaboration with experts and assisted preparation of the manuscript. 
Appendix 1. Poster on sea shells of Lakshadweep protected under Wildlife (Protection) Act of India

\section{SEA SHELLS OF LAKSHADWEEP PROTECTED UNDER WILDLIFE (PROTECTION) ACT OF INDIA}

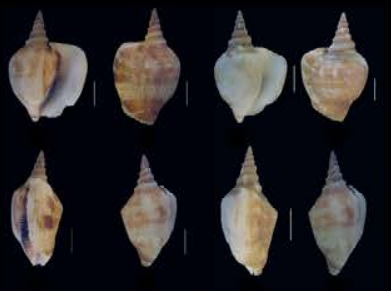

Sibbald's Conch (Various forms

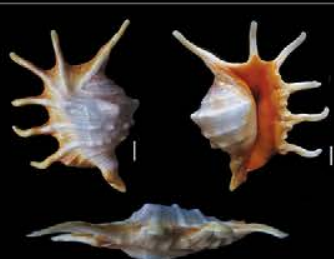

4. Lambis crocata (Link, 1807)

Orange Spider Conch

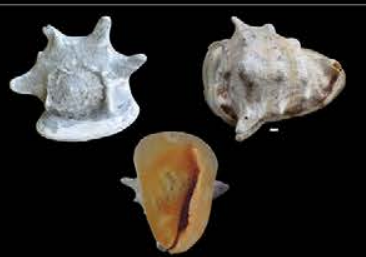

Cassis cormuta (Linnaeus, 1758) Horned Helmet

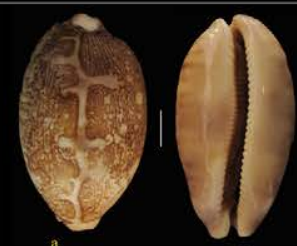

11. Leporicypraea mappa (Linnacus, 1758) Map cowrie

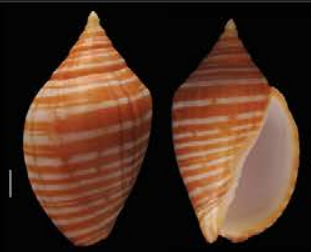

15. Harpulina arausiaca (Ligthfoot, 1786) Vaxillate Volute

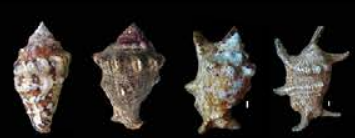

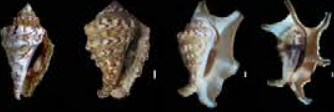

2. Harpago chiragra (Linnaeus, 1758)

Chiragra Spider Conch (Various life stages)
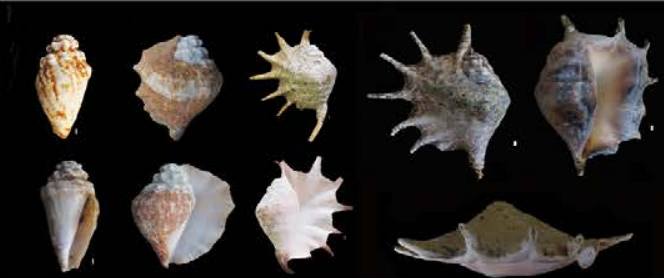

5. Lambis truncata ([Lightfoot], 1786)

Truncate spider Conch (Various life stos )

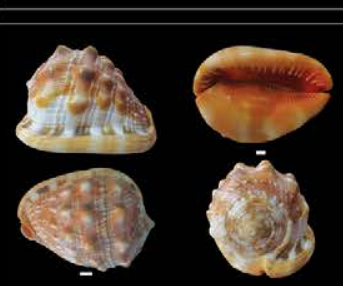

8. Cypraecassis rufa (Linnaeus, 1758) Bull Mouth Helmet
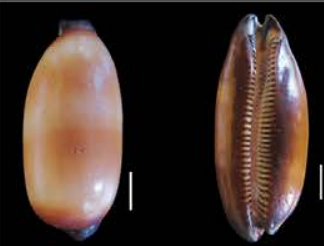

12. Talparia talpa (Linnaeus, 1758) Mole Cowric

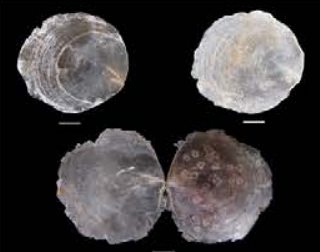

16. Placuna placenta (Linnaeus, 1758) WindowPane Oyster

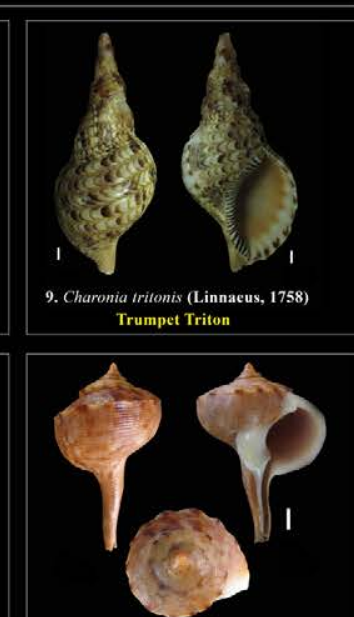

13. Tudicla spirillus (Linnacus, 1767) Dog Chunk
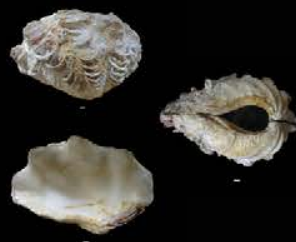

17. Tridacna maxima (Röding, 1798) Elongate Giant Clam

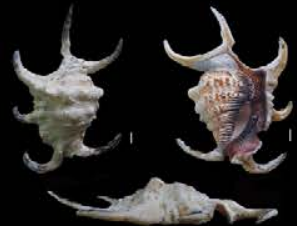

3. Harpago arthriticus (Rỉiding, 1798) Arthritic Spider Conch

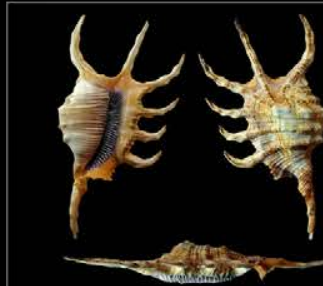

6. Lambis indomaris Abbott, 196 Scorpio Conch

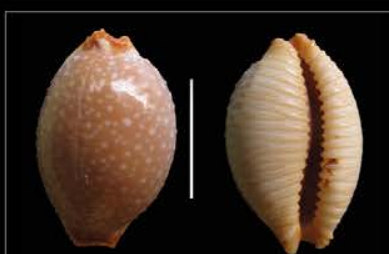

10. Staplylaca limacina (Lamarck, 1810) Limacina Cowrie

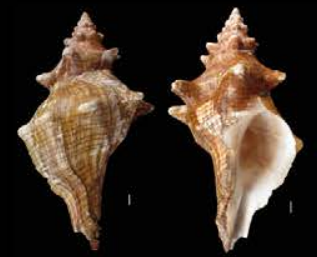

14. Pleuroplaca trapezium (Linnacus, 1758) Trapezium Horse Conch
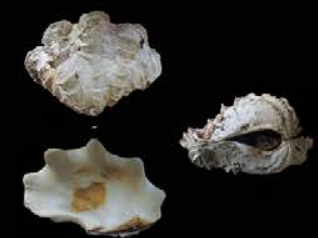

18. Tridacna squamosa Lamarck, 1819 Fluted Giant Clam
DEPARTMENT OF AQUATIC BIOLOGY AND FISHERIES University of Keral

Thiruvananthapuram-695581, Kerala, India

Schedule I: Figs. 7,8,9,13,17,18,19

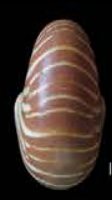

19. Nautilus pompilius Linnaeus, 1758 Chambered Nautilus

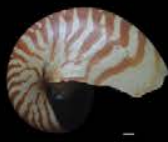

DEPARTMENT OF SCIENCE AND TECHNOLOGY Kavaratti U.T. of Lakshadweep 682555 , India

Schedule IV: Figs. 1,2,3,4,5,6,10,11,12,14,15,16 Scale bar $=1 \mathrm{~cm}$
$\operatorname{logy}$ and Fisheries Poster $\odot$ Department of Aquatic Biology and Fisheries
Zes 